\title{
SLÓW KILKA O MOSINIE (NA MARGINESIE BADAŃ ARCHEOLOGICZNYCH PRZEPROWADZONYCH NA MOSIŃSKIEJ STARÓWCE W 2011 R.)
}

\author{
A FEW WORDS ABOUT MOSINA \\ (IN THE CONTEXT OF ARCHAEOLOGICAL EXCAVATIONS \\ CONDUCTED IN THE OLD TOWN IN MOSINA IN 2011)
}

\author{
Anna Cicha \\ Instytut Archeologii Uniwersytetu Mikołaja Kopernika w Toruniu \\ ul. Szosa Bydgoska 44/48, 87-100 Toruń, Mosina; Poland \\ kuki01@wp.pl \\ Piotr Wawrzyniak \\ Pracownia Archeologiczno-Konserwatorska mgr Alina Jaszewska \\ ul. Ceramiczna 2, 65-954 Zielona Góra \\ Oddział w Poznaniu, ul. Woźna 12, 61-677 Poznań, Poland \\ wawrzyniakp@poczta.fm
}

\begin{abstract}
The archaeological excavations conducted in the spring of 2011 in yard No. 7 in the vicinity of old market at Plac 20 Października (20th October Square) were the first in the history of the town large-scale investigations of residential urban area in Mosina. Late-medieval and modern relics of buildings have been unearthed, and an extremely interesting assemblage of the fifteenth-eighteenth century pottery and small objects of everyday use collected. The absence of materials dating from the fifteentheighteenth-century Middle Ages speaks in favour of the thesis suggested by researchers that Mosina might have been translocated into its present location from neighbouring Niwka.
\end{abstract}

KEY WORDS: Mosina, Niwka, town, status, location, plot, trench, stratigraphy, wooden buildings, log construction, post-and-plank construction, clay vessels, reduction firing, oxidation, Middle Ages, Modern Times.

\author{
Mały Paryż to miasto \\ nieopodal Poznania, \\ gdzie ,Sekwana” się wije \\ $i$ elegant się ktania. \\ R. Habdas, Maty Paryż
}

„Mały Paryż” - tak właśnie o położonym $20 \mathrm{~km}$ na południe od Poznania miasteczku Mosina wypowiedział się kiedyś Roman Habdas (Habdas 1987, s. 8). Mimo tego pięknego określenia miasto to, pozostające od wieków w cieniu poznańskiej 
metropolii, otulone wzgórzami morenowymi i zakolem Warty, z pozoru uśpione, nigdy nie miało większego znaczenia w regionie. Był nawet i czas, gdy - jak pisał Oskar Kolberg - „miasteczko to niedaleko Poznania jest także bardzo pogardzonem” (Pruchniewska 1987, s. 5). Z drugiej strony „w Mosinach, gdzie lubo nas postawiono było..." odpoczywał wraz z wojskami hetmana Czarnieckiego Jan Chryzostom Pasek, zachwalając sobie wielce to miejsce (Pasek 2006, s. 41-42). W miasteczku aż trzykrotnie miał przebywać Napoleon Bonaparte, m.in. podczas wyprawy na Moskwę w 1812 r. Studnia, z której wówczas pił wodę, istnieje do dzisiaj, a według legendy jej wody raz do roku zamieniają się w szampana (Sobczak 2007, s. 27-29; Gazeta... 2012). Mosina to także miejsce narodzin Immanuela Lazarusa Fuchsa wybitnego niemieckiego matematyka, rektora Uniwersytetu Berlińskiego (Łęcki 2002, s. 63-64). Wreszcie, właśnie to małe miasto przez kilka majowych dni roku 1848 dzięki powstańczym oddziałom Jakuba Krauthofera-Krotowskiego nosiło miano stolicy odrodzonej Rzeczypospolitej (Łojko i Stępień 1992, s. 38-39). Archeologom Mosina powinna kojarzyć się przede wszystkim ze znajdującą się na opłotkach miasta wsią Sowinki, gdzie pod koniec lat 80 . XX w. odkryto potężne cmentarzysko wczesnośredniowieczne, m.in. z pochówkami o cechach skandynawskich (Krzyszowski 1992, s. 83-102). Samo miasto - mimo że stanowiące jedną z najstarszych lokacji w Wielkopolsce - nie było przez lata poddane badaniom archeologicznym. Autorzy monografii miasta i okolic - Jerzy Łojko i Jerzy Stępień - pisali 20 lat temu: „słabo pod względem archeologicznym jest rozpoznany okres średniowieczny XIII-XV wiek" (Łojko, Stępień 1992, s. 12). O badaniu dziejów miasta nowożytnego nikt nawet wówczas zapewne nie myślał. Sytuacja ta zaczęła się zmieniać $\mathrm{z}$ początkiem nowego wieku, w związku z prowadzonymi $\mathrm{w}$ mieście inwestycjami wraz z towarzyszącymi im badaniami i nadzorami archeologicznymi (E. Pawlak, P. Pawlak 2014, s. 249).

Najstarsza wzmianka o Mosinie - jako o rzeczce - pochodzi z 1247 r.: ,,rok następujący ujrzał różne w państwach koronnych odmiany. Książęta Wielkopolscy wspólnie dotąd w udziale swoim panujący, rozdzielili między sobą prowincję, zwoławszy na ten koniec zjazd szlachetny do Poznania. Bolesławowi młodszemu dostało się Księstwo Kaliskie od rzeki Prosny aż do Przemętu, wespół z tym zamkiem, a stamtąd do rzeki Warty, do Moszyny, jeziora Sempna, Lanki i rzeki Odry” (Roszak 1987, s. 1). Datą 1 lutego 1302 r. opatrzony jest dokument wojewody kaliskiego, Mikołaja Przedpełkowica, potwierdzający decyzję o powstaniu miasta (Łojko i Stępień 1992, s. 15-16). Chociaż zwyczajowo mówi się o nim jako o akcie lokacyjnym i uznaje się ten moment za początek miasta Mosina, wydaje się, iż sama miejscowość nie tylko istniała wcześniej, ale również podejmowano już uprzednio próby (nieudane) jej lokacji. Według Zbyszka Górczaka Mosina mogła być lokowana już za rządów Przemysła II, a sam komes Mikołaj Przedpełkowic aż dwukrotnie przenosił miejscowość, nim wyznaczył jej zajmowane do dziś miejsce (Górczak 2002, s. 110, 129). Warto zwrócić uwagę, że dokument z 1302 r. zawiera m.in. na- 
stępujący fragment: ,z korzystnym wynikiem, na nowo wydzierżawiliśmy i przywróciliśmy do poprzedniego stanu naszą posiadłość zwaną niegdyś Mosiną [...] odnowiliśmy ordynację miasta Mosina" (Kodeks... 1878, nr 848). Problem lokacji i ewentualnej translokacji Mosiny to także problem jej związków z nadwarciańską wsią Niwka. Miejscowość ta położona jest około $5 \mathrm{~km}$ na północ od Mosiny i stanowi dziś dzielnicę miasta Puszczykowo. Warto nadmienić, iż w trakcie prac archeologicznych prowadzonych w rejonie Niwki w latach 80 . XX w. natrafiono na ślady XIII-wiecznej osady (Łojko i Stępień 1992, s. 9). Istnieje przypuszczenie, że to właśnie Niwka miała być miejscem pierwszej lokacji miasta lub też stanowić miała dla niego nazwę - według dokumentu z 1302 r., wymieniającego obydwie nazwy, Mosina była określeniem dawnym i potocznym, a nowe miasto powinno nazywać się Niwka (Łojko i Stępień 1992, s.15). Z dokumentu wynika także, iż miasteczko miało młyn, łaźnię oraz trzy kramy rzeźnicze (Kodeks... 1878, nr 848; Łojko, Stępień 1992, s. 16). Trudno jednak orzec, jak ostatecznie przebiegła lokacja z przełomu XIII i XIV stulecia. Miasto doczekało się bowiem kolejnego przywileju lokacyjnego - wystawionego przez Władysława Jagiełłę 2 lipca 1429 r. Niektórzy badacze, w tym autorzy Słownika geograficznego Królestwa Polskiego i innych krajów słowiańskich, sugerowali, iż dopiero ten drugi akt jest rzeczywistym początkiem miasta Mosina (Sulimierski, Chlebowski, Walewski 1885, s. 702-703). Wydaje się jednak, że miasto mimo wszystko musiało jednak funkcjonować jako takie już w XIV stuleciu, gdyż z końca tego wieku i początku następnego znani są z imienia mosińscy wójtowie oraz osoby określane jako mieszczanie mosińscy (Łojko, Stępień 1992, s. 18). Przywilej króla miał prawdopodobnie na celu potwierdzenie dla miasteczka prawa magdeburskiego, ponadto otrzymało ono przywilej odbywania dwóch jarmarków rocznie - w dzień św. Urbana, tj. 25 maja, i 6 grudnia - w dzień św. Mikołaja, będącego patronem parafii (Łojko, Stępień 1992, s. 17). Jednak przy założeniu, że pierwotnie Mosina ulokowana była na miejscu dzisiejszej Niwki, przywilej królewski zapewne wiązałby się z jej translokacją na obecne miejsce i potwierdzeniem praw miasta po przeniesieniu.

Przez kolejne lata Mosina zachowywała status małego miasta - w trakcie wojny z zakonem krzyżackim w 1458 r. zobowiązana była wystawić zaledwie 4 żołnierzy (Łojko, Stępień 1992, s. 19). W okresie nowożytnym Mosina należała do tzw. „miasteczek rolniczych", niemających znaczenia administracyjnego, kościelnego czy kulturalnego, których mieszkańcy żyli głównie z uprawy roli (Górczak 2002, s. 14-15). W tym czasie jednak Mosina rozwijała lokalną wytwórczość garncarską, opartą na bogatych złożach gliny występujących w podległej miastu wsi Pożegowo (dziś stanowiącej dzielnicę Mosiny). Pod koniec XVIII w. miasto miało 21 garncarzy - tyle samo co Poznań, z tą jednak różnicą, że Mosina liczyła w tym czasie 419 mieszkańców, a Poznań ponad 12 tys. (Kruppé 1983, s. 136). Jeszcze w połowie XIX w. Józef

\footnotetext{
${ }^{1}$ Tłumaczenie z łaciny - Janina Krupa.
} 


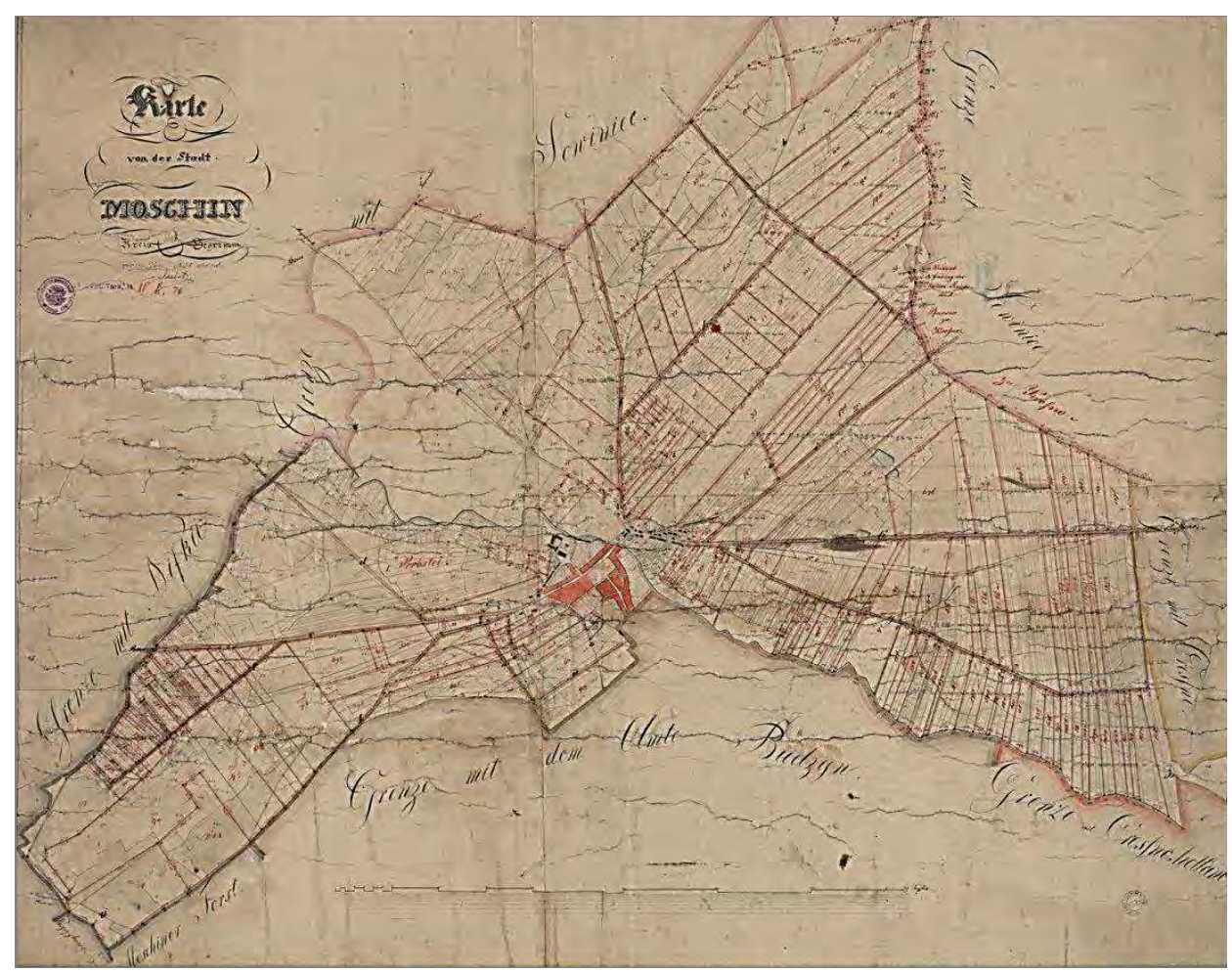

Ryc. 1. Mosina, gm. loco, Plac 20 Października nr 7. Badania archeologiczne, 2011 r. Jedna z najstarszych map Mosiny - Karte von der Stadt Moschin, 1831 (Archiwum Państwowe w Poznaniu, sygn. L. Srem 68). Widoczny w centrum miasta rynek i parcele przyrynkowe

Fig. 1. Mosina, com. loco, Plac 20 Października No. 7. Archaeological excavations in 2011. One of the oldest maps of Mosina - Karte von der Stadt Moschin 1831 (National Archive in Poznań, Inv. No. L. Srem 68). In the centre - a market and surrounding yards

Łukaszewicz pisał: „miasteczko Mosina osiadłe samymi prawie garncarzami” (Lukaszewicz 1858, s. 274). Od końca XIX stulecia te tradycje kontynuowała działająca na obrzeżach miasta cegielnia Maksymiliana Perkiewicza.

Miasto nigdy nie miało murów miejskich. Centralne miejsce zajmuje rynek, a pierwotna siatka ulic jest wyraźnie w topografii miasta czytelna do dziś (ryc. 1). Mosiński plac rynkowy należy do stosunkowo dużych. O jego rozplanowaniu w okresie średniowiecza nic nie wiadomo, natomiast w czasach nowożytnych (od ok. drugiej połowy XVII w. do $1816 \mathrm{r}$.) połowę placu zajmował drugi z tutejszych kościołów - św. Stanisława - wraz ze szpitalem i cmentarzem (Łojko, Stępień 1992, s. 93-94; Łukaszewicz 1858, s. 275-276). Właściwy kościół parafialny (dawniej pw. św. Mikołaja i św. Wawrzyńca) podobnie jak w innych miasteczkach wielkopolskich usytuowany został w niewielkim oddaleniu od rynku, przy ulicy wychodzącej z jego 
północno-wschodniego narożnika. Zabudowę dzisiejszego rynku stanowią budynki z XIX, XX i XXI w. Są to w większości jednopiętrowe kamienice, niektóre wzbogacone o mansardowe drugie piętro. Budynki mają prostą formę, a elewacje pozbawione są dodatkowych zdobien - zaakcentowane zostały jedynie gzymsy, niekiedy wprowadzono pilastry i boniowania. Na tym tle wyróżniają się dwa budynki, w tym najokazalsza z mosińskich kamienic, stanowiąca na przełomie XIX i XX w. siedzibe sanatorium „Obrabad”, w pierzei południowej, oraz budynek Urzędu Miasta - dawny hotel, w pierzei północnej.

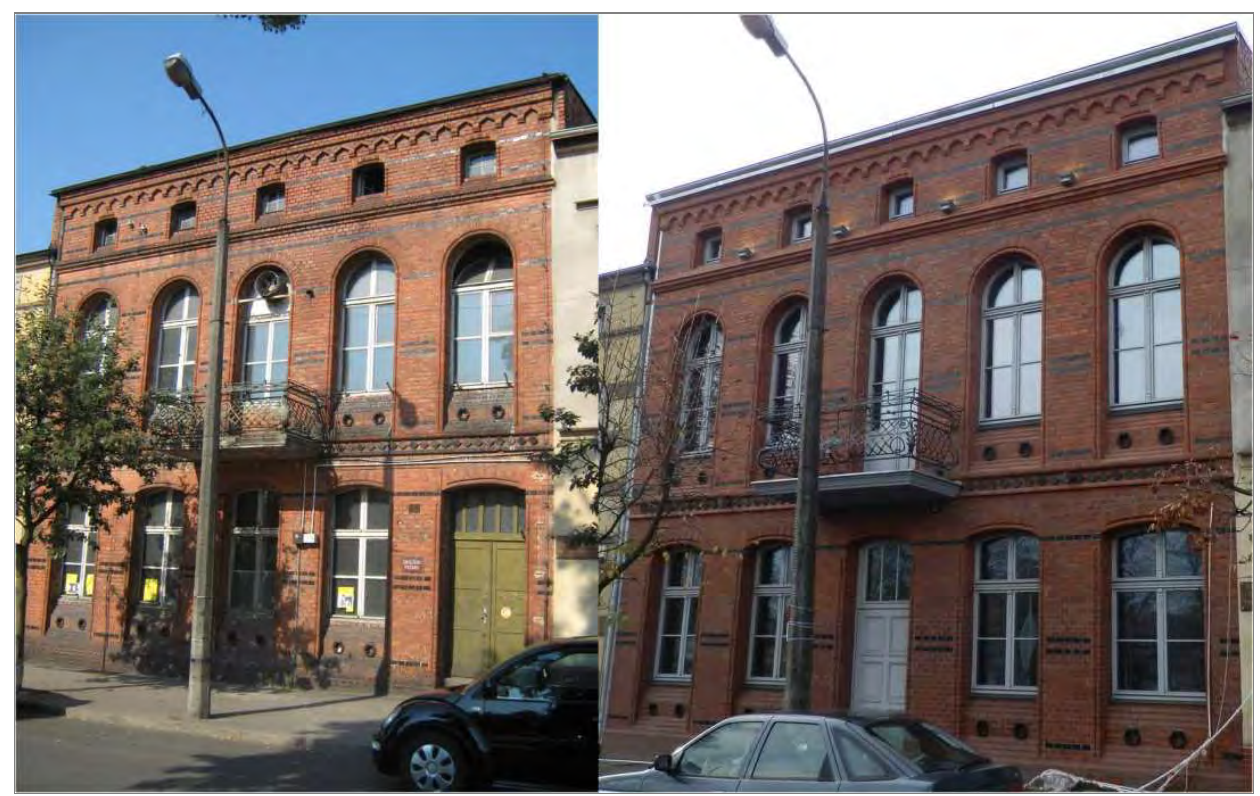

Ryc. 2. Mosina, gm. loco, Plac 20 Października nr 7. Badania archeologiczne, 2011 r. Budynek pod nr 7 przy mosińskim rynku - dawna restauracja, hotel i szwalnia. Po lewej stan przed remontem (czerwiec 2011 r.), po prawej po remoncie (listopad 2012 r.) (fot. A. Cicha, P. Wawrzyniak)

Fig. 2. Mosina, com. loco, Plac 20 Października No. 7. Archaeological excavations in 2011. Building at No. 7 at the market in Mosina - a former restaurant, hotel and sewing house. Left - before renovation (June 2011), right - after (November 2012) (photo by A. Cicha, P. Wawrzyniak)

Zwraca też uwagę budynek znajdujący się w pierzei zachodniej, pod numerem 7 . Choć formą swą (jednopiętrowy budynek na planie prostokąta zamknięty prostym dachem) wpisuje się w otaczającą go zabudowę, to wygląd jego zdecydowanie odbiega od reszty kamienic. Fasada obłożona została cegłami licowymi z zastosowaniem poziomych pasów ciemnej cegły klinkierowej i ozdobnego fryzu między kondygnacjami, również z klinkierowych kwadratowych płytek. Pod dachem ciągnie się ceglany fryz arkadkowy. Pięcioosiowy układ elewacji wyznaczają duże okna 
(w przyziemiu sklepione odcinkowo, na piętrze zamknięte łukiem pełnym), znajdujące się w wysokich wnękach okiennych o krawędziach zdobionych półwałkiem i sześciobocznych, przypominających kwiaty, klinkierowych detalach w dolnych partiach. Na piętrze budynku w osi środkowej znajduje się balkon o kutej, secesyjnej balustradzie. Na parterze, w skrajnej lewej (prawej z perspektywy widza) osi budynku pierwotnie umiejscowione były wysokie, wąskie drzwi - po ostatnim remoncie wejście zostało przeniesione do osi środkowej i elewacja stała się bardziej symetryczna. Całość budynku przywodzi na myśl raczej pruską architekturę budynków użyteczności publicznej lub industrialnych niż kamienicę małego miasta (ryc. 2).

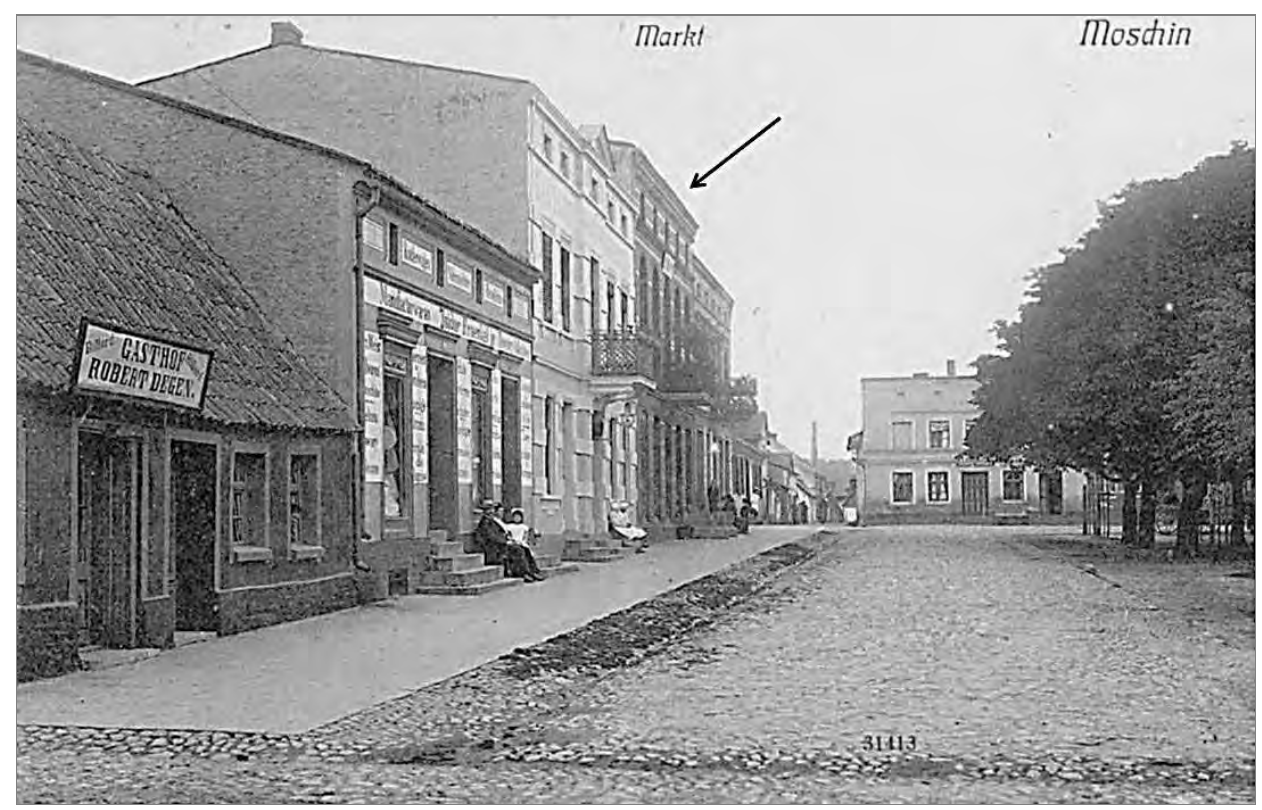

Ryc. 3. Mosina, gm. loco, Plac 20 Października nr 7. Badania archeologiczne, 2011 r. Zachodnia pierzeja mosińskiego rynku na pocztówce z początku XX w. ze wskazaniem omawianego budynku

Fig. 3. Mosina, com. loco, Plac 20 Października No. 7. Archaeological excavations in 2011. Western plot of the market in Mosina - a view card from the beginning of the twentieth century with the discussed building marked

Według informacji zawartych w Gminnej Ewidencji Zabytków Miasta i Gminy Mosina budynek ten powstał na początku XX w. z przeznaczeniem na hotel/karczmę/restaurację. Jacek Szeszuła ocenia, iż obiekt zbudowano w przybliżeniu w latach 1885-1890 (Szeszuła 2012, s. 1). Wspomnianym celom hotelowo-restauracyjnym służył przez pierwszych kilkadziesiąt lat swojego istnienia. Budynek z szyldem hotelu widoczny jest na pocztówkach mosińskich z początku XX stulecia 
(ryc. 3$)^{2}$. W przeciwieństwie do wielu innych kamienic przy mosińskim rynku jego wygląd praktycznie nie uległ zmianom. W 1904 r. podpisany jest jako „Hotel Degen”3, w 1907 jako „Hotel Post”. O reprezentacyjnym pierwotnym przeznaczeniu budynku świadczyły również zachowane do niedawna niektóre elementy w jego wnętrzu - klatka schodowa i fresk na ścianie, osadzone w stylistyce secesyjnej. Po pierwszej wojnie światowej obiekt nie tracąc swojego przeznaczenia, przeszedł w ręce Polaków - wiadomo, iż w 1928 r. posesję zakupiło małżeństwo Cecylia i Michał Stanikowscy, i w ich gestii zabudowa ta pozostawała kilkadziesiąt lat ${ }^{4}$. W okresie międzywojennym budynek mieścił restaurację, kawiarnię, winiarnię i hotel „Wolność” (Szeszuła 2012, s. 1). Stanowił tym samym jedną z 11 restauracji i 3 hoteli w ówczesnej Mosinie (Łojko, Stępień 1992, s. 46). Sala na pierwszym piętrze miała charakter widowiskowo-konferencyjny i służyła balom rozmaitych towarzystw oraz organizacji, mityngom wyborczym i zebraniom. Tak miejsce to wspomina ówczesny mieszkaniec Mosiny, Henryk Kołtoniak:

W restauracji Michała Stanikowskiego, dom pod nr 7 w Rynku, odbywały się często różne bale, wenty, wieczornice, spotkania. Organizatorami byli z reguły mosińscy rzemieślnicy, [tacy] jak: piekarze, rzeźnicy, restauratorzy, ale i Sokoły, i Sokolice (Towarzystwo Gimnastyczne), Bractwo Kurkowe. Michał Stanikowski, Powstaniec Wielkopolski, był jego aktywnym członkiem. W połowie lat 30. został Królem Kurkowym. Każda z tych grup miała swoich sympatyków i bywalców. Patrzyłem na to z okien naszego domu pod nr 8, oczami dziecka 10-14-letniego w latach 1935-1939. Jeszcze dzisiaj „widzę” podjeżdżające pod restaurację powozy konne, wytworne w ówczesnym czasie toalety pań, panów w eleganckich frakach i smokingach, z cylindrami, melonikami na głowach lub w ręku, towarzyszących swoim wybrankom. Bawiono się do białego rana (Szeszuła 2012, s. 1-2)

Pewną ciekawostką jest to, iż w połowie lat 30. ubiegłego stulecia w dużej części oficyny zorganizowano sale lekcyjne dla kilku najmłodszych klas szkoły podstawowej (ze względu na przepełnienie właściwych budynków szkolnych).

Budynek pod nr 7 zapisał się również w tragicznej historii miasta z okresu drugiej wojny światowej, kiedy to Mosina stała się jednym z miejsc pierwszych masowych egzekucji w ramach operacji „Tannenberg”. 20 października 1939 r. w sali na pierwszym piętrze budynku odbył się hitlerowski „sąd doraźny” (Sondergericht) nad 21 obywatelami miasta i okolicy, których aresztowano kilka dni wcześniej i prze-

\footnotetext{
${ }^{2}$ Pocztówki ze zbiorów Biblioteki Uniwersyteckiej w Poznaniu, ze strony internetowej miasta Mosina (www.mosina.pl) oraz ze zbiorów prywatnych autorki.

${ }^{3}$ Być może chodzi o właściciela, Roberta Degena? Takie nazwisko widoczne jest na innej pocztówce na szyldzie nieistniejącego już budynku (dwie kamienice dalej), na rogu rynku i obecnej ulicy Krauthofera-Krotowskiego - Gasthof Robert Degen.

${ }^{4} \mathrm{Za}$ zebranie informacji na temat dziejów budynku pod $\mathrm{nr} 7$ autorzy składają serdeczne podziękowanie mosińskiemu historykowi, Panu Jackowi Szeszule.
} 
trzymywano w budynku dawnej bożnicy. Piękne secesyjne schody budynku zajmował wówczas szpaler niemieckich żołnierzy, między którymi musieli przejść popędzani i bici aresztanci. To właśnie w tym budynku zapadł wyrok skazujący 15 mieszkańców na śmierć przez rozstrzelanie. Wyrok wykonano jeszcze tego samego dnia pod murem w tej samej pierzei rynkowej. Dla upamiętnienia tamtych tragicznych wydarzeń mosiński rynek nosi dziś nazwę Placu 20 Października. Rodzina Stanikowskich w tym czasie została zmuszona do opuszczenia domu, a Michał Stanikowski, aresztowany w 1940 r. przez Gestapo, zginął w 1942 w Konzentrationslager Auschwitz. Dawna restauracja pod nr 7 pozostawała zamknięta, a pomieszczenia części hotelowej wykorzystywane były na potrzeby wojska.

Po drugiej wojnie światowej Cecylia Stanikowska powróciła do Mosiny i wznowiła działalność restauracji. Prowadziła ją do 1951 r. Nie działała już jednak część hotelowa, a oficyny przerobiono na mieszkania. Jeszcze w 1945 r. przy nieodległej ulicy Słowackiego założono szwalnię, którą w 1952 przeniesiono do budynku dawnej przyrynkowej restauracji pod nr 7 (Roszak 1986, s. 4; Szeszuła 2012, s. 2). Przekształcenie gmachu na szwalnię pociągnęło za sobą istotne zmiany we wnętrzach, choć pozostawiło w niemal niezmienionej formie elewację frontową. Od $1977 \mathrm{r}$. szwalnia stanowiła jeden z oddziałów zakładów „POLSPORT”. Rodzina Stanikowskich zatrzymała dawną część hotelową $\mathrm{w}$ oficynach, a po likwidacji szwalni w 1993 r. rozpoczęła starania o odzyskanie budynku frontowego. Cel ten osiągnęła na przełomie lat 2006-2007. Wkrótce zadecydowano o sprzedaży całej parceli budynku restauracyjnego i hotelowych oficyn. Posesję zakupił lokalny przedsiębiorca, Tomasz Olejniczak, z planem nadania temu miejscu charakteru pasażu handlowego (Szeszuła 2012, s. 3).

Pojawiła się szansa, iż nieużytkowany od ponad 20 lat piękny, zabytkowy budynek w samym centrum Mosiny odzyska swoje znaczenie w codzienności miasteczka. Nieoczekiwanie też prace archeologiczne prowadzone podczas remontu $\mathrm{w}$ jego wnętrzu przyniosły interesujące odkrycia na temat dawnej Mosiny.

$$
* * *
$$

Badania wykonano w drugiej połowie maja - początkach czerwca $2011 \mathrm{r}^{5}$. Niestety zrealizowane wcześniej, bez obecności archeologa, roboty ziemne spowodowały bezpowrotne zniszczenie nawarstwień kulturowych w kilku punktach działki. Niemniej już pierwszy ogląd zastanej sytuacji utwierdził prowadzących badania o celowości podjęcia natychmiastowych działań ratowniczych na terenie całej posesji, a w szczególności w pomieszczeniach piwnicznych budynku przedniego.

\footnotetext{
${ }^{5}$ Kierował nimi mgr P. Wawrzyniak w ścisłej współpracy z mgr E. Pawlak i dr. Ł. Gilem z Pracowni Archeologiczno-Konserwatorskiej mgr Alina Jaszewska z siedzibą w Zielonej Górze, Oddział w Poznaniu.
} 
Poddana czynnościom badawczym parcela o wymiarach $60,75 / 67,15 \times 11,2 / 11,5 \mathrm{~m}$ (około $700 \mathrm{~m}^{2}$ ) znajduje się w środkowej części północno-zachodniego bloku zabudowy przyrynkowej, usytuowanego między płytą rynku (od wschodu) a ulicami: Tylną (od północy i zachodu) oraz Krotowskiego (od południa). Działka została onegdaj wytyczona przez mierniczych ,na przestrzał”, od placu rynkowego aż po uliczkę zatylną. Wydaje się, że zachowała ona, podobnie jak sąsiednie, swój pierwotny zasięg oraz kształt.

Obecna, częściowo podpiwniczona, zabudowa działki oraz gęsta sieć podziemnych instalacji komunalnych mocno ograniczyły możliwość zakładania wykopów. Badaniami objęto przede wszystkim front parceli, wykonano także niewielki sondaż

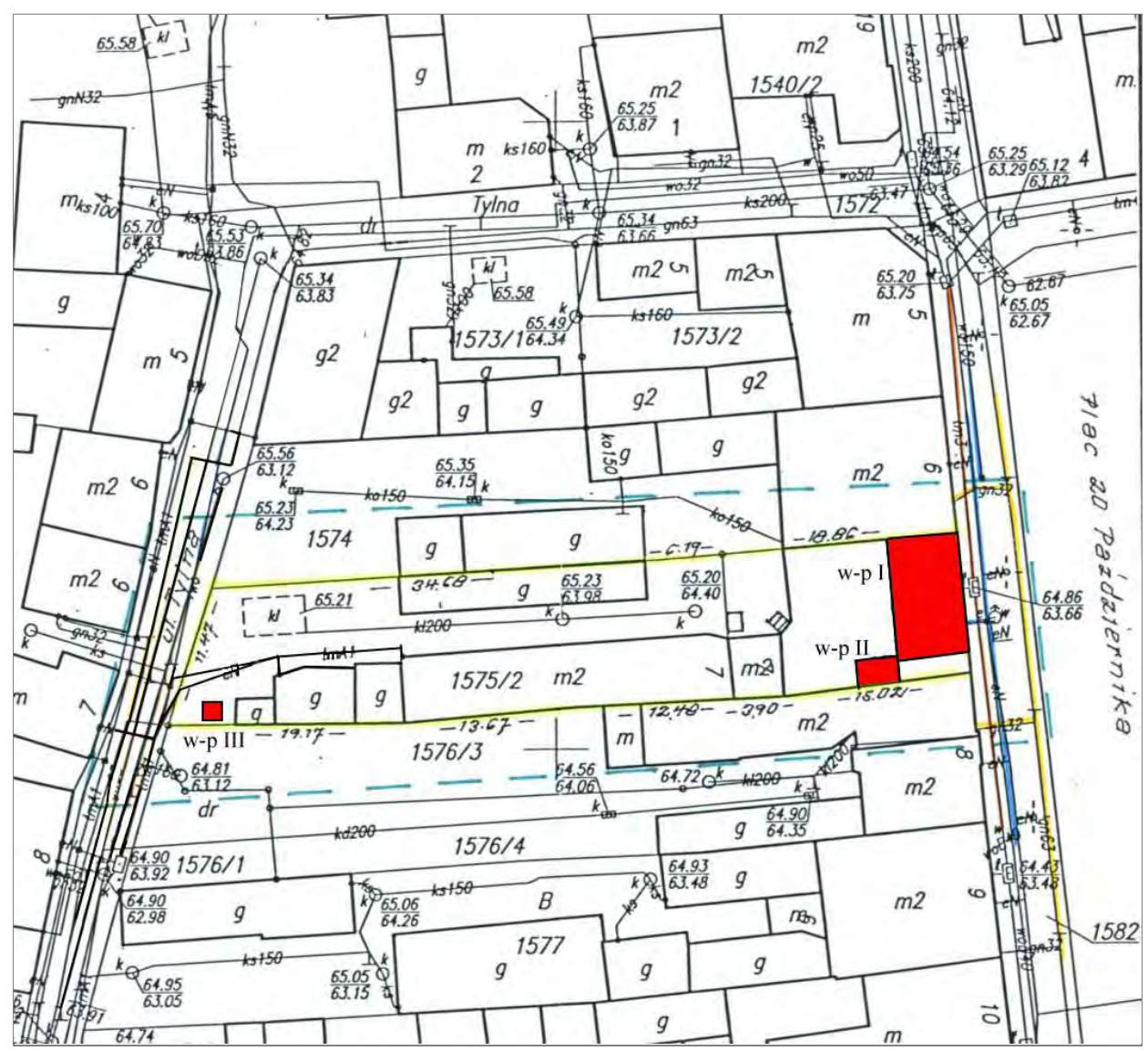

Ryc. 4. Mosina, gm. loco, Plac 20 Października nr 7. Badania archeologiczne, 2011 r. Lokalizacja parceli i wykopów badawczych (oprac. P. Wawrzyniak)

Fig. 4. Mosina, com. loco, Plac 20 Października No. 7. Archaeological excavations in 2011. Location of the plot and archaeological trenches (by P. Wawrzyniak) 


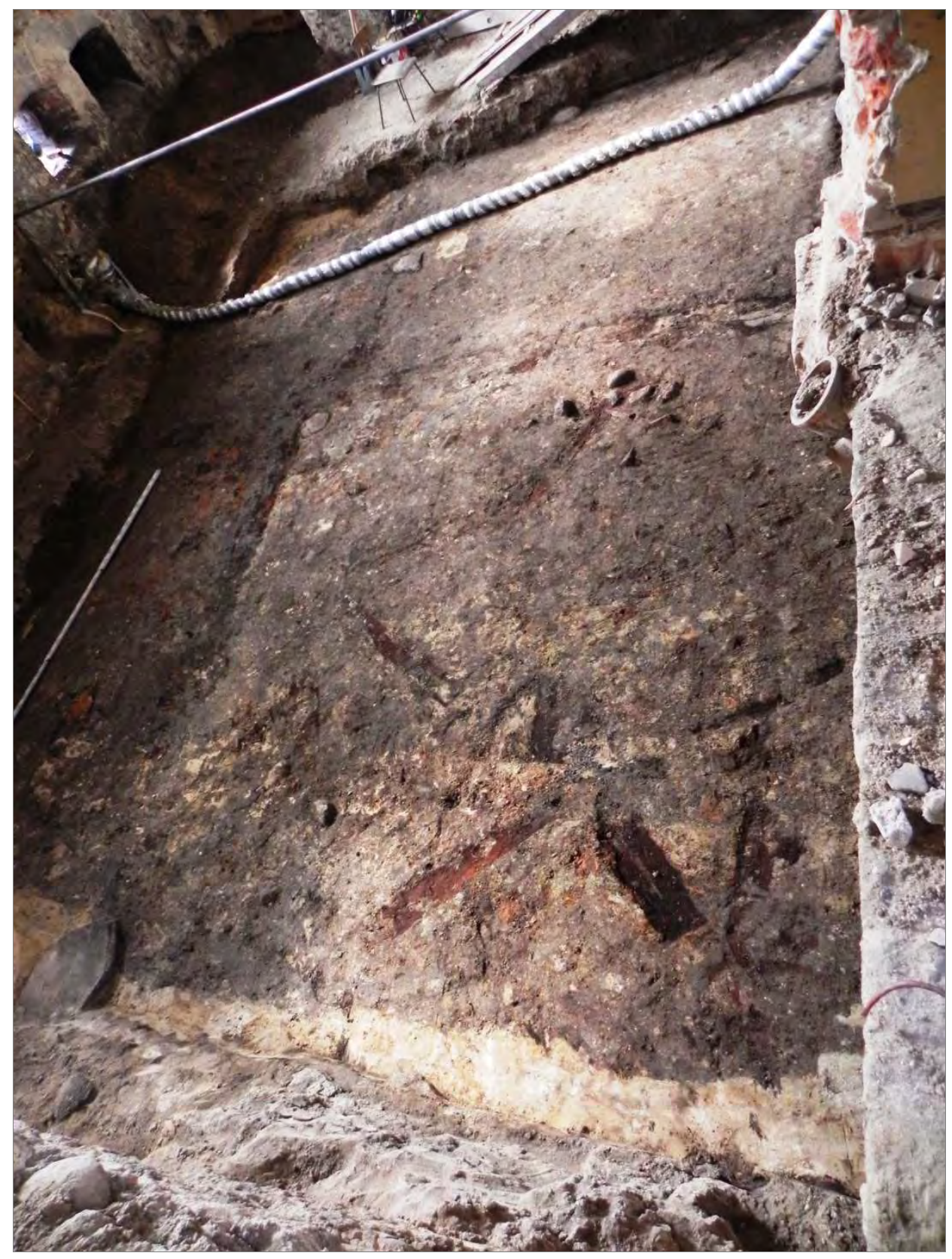

Ryc. 5. Mosina, gm. loco, Plac 20 Października nr 7. Badania archeologiczne, 2011 r. Odsłonięte relikty domu drewnianego z drugiej połowy XVII-XVIII w. (fot. E. Pawlak)

Fig. 5. Mosina, com. loco, Plac 20 Października No. 7. Archaeological excavations in 2011. Unearthed relics of a wooden house from the second half of the seventeenth-eighteenth century (photo by E. Pawlak) 
na jej tyłach, w bezpośrednim sąsiedztwie ul. Tylnej (ryc. 4). Ponadto sprawowano ścisły nadzór archeologiczny nad wszelkimi robotami ziemnymi prowadzonymi na budowie. Ich zasięg był jednak niewielki i najczęściej ograniczał się do stosunkowo niewielkich wkopów pod instalacje energetyczne bądź wodociągowe.

Główny wysiłek badawczy skoncentrowano na eksploracji nawarstwień w pomieszczeniu piwnicznym $\mathrm{nr} 06$ usytuowanym pod dawną restauracją. Zlokalizowany tutaj wykop $\mathrm{nr}$ I miał wymiary $8,7 \times 6,5 \mathrm{~m}$. Jego niezbyt regularny kształt oraz rozmiary zostały podyktowane zastanymi warunkami i wymogami bezpieczeństwa pracujących ${ }^{6}$. W miarę pogłębiania wielkość wykopu ulegała systematycznemu pomniejszaniu, by w ostatecznym rozrachunku przybrać wartość ok. 7,95 × 4,5 m. Prace wykopaliskowe prowadzono od wysokości około 62,8 do $62,0 \mathrm{~m} \mathrm{n.p.m.}{ }^{7}$, wydzielając trzy podstawowe układy stratygraficzne, które oznaczono jako poziomy nr I-III (ryc. 6, 9 i10).

W stropie pierwszego z tych poziomów, w części zachodniej wykopu, zarysowały się na wysokości ok. 62,63-62,52 m n.p.m. kontury stosunkowo dużego, zorientowanego na osi wschód-zachód budynku drewnianego, po stronie północnej zbudowanego w technice zrębowej, a południowej prawdopodobnie - sumikowo-łątkowej (ryc. 5). Jego front o szerokości $8,45 \mathrm{~m}$ był oddalony o ok. 3,5/3,9 m od obecnej linii zabudowy pierzei zachodniej placu rynkowego. Dalsza eksploracja reliktów tegoż budynku przyniosła odsłonięcie znacznej partii kilkuizbowego założenia o ścianach wzniesionych z belek o szerokości 0,25/0,35 m, zagłębionego w ziemi na co najmniej $0,6 \mathrm{~m}$ w części północnej i $1,1 \mathrm{~m} \mathrm{w}$ południowej ${ }^{8}$. Ze ścian budowli zachowały się tylko mocno rozłożone fragmenty belek podwalin wsparte na dużych, płaskich kamieniach polnych ${ }^{9}$. Pierwsza z rozpoznanych izb przednich północna (obiekt nr 1a) - miała wymiary $4 \times 4,6 \mathrm{~m}$. Taką samą szerokość, tj. 4,6 m, miała usytuowana bezpośrednio za nią izba tylna (? - obiekt nr 1b). Natomiast dostawiona (?) do swoich północnych sąsiadów południowa izba przednia (obiekt $\mathrm{nr} 2$ ), o froncie cofniętym o ok. $0,4 \mathrm{~m} \mathrm{w}$ stosunku do całości, miała wymiary $4 \times 3,85 \mathrm{~m}$ i część środkową przegłębioną na kilkadziesiąt centymetrów, być może pozostałości piwniczki z domniemanym wejściem od strony zachodniej (ryc. 6).

\footnotetext{
${ }^{6}$ Wymogi bezpieczeństwa stanęły na przeszkodzie w dalszej eksploracji wykopu nr II zlokalizowanego w sąsiednim pomieszczeniu piwnicznym $\mathrm{nr}$ 07. Do momentu przerwania prac w wykopie rejestrowano tylko współczesne nawarstwienia gruzowe.

${ }^{7}$ Pomieszczenie nr 06, częściowo zasypane w bliżej nieokreślonym czasie, zostało odkopane do rzeczonej wyżej wartości od poziomu obecnego przyziemia budynku, który wynosi $65,2 \mathrm{~m}$ n.p.m. Pierwotnie było podzielone na trzy mniejsze lokalności. Ślady tych podziałów zachowały się w formie strzępi na murach wschodnim i zachodnim wspomnianej piwnicy oraz w stropie wykopu nr I jako biegnące po osi wschód-zachód zarysy wkopów pod ławy fundamentowe poszczególnych ścian działowych (ryc. 6).

${ }^{8} \mathrm{~W}$ narożu północno-wschodnim pomieszczenia piwnicznego szczęśliwie zachował się świadek ziemny, który pozwolił określić pierwotny poziom stropu calca. Wynosił on ok. $63,05 \mathrm{~m}$ n.p.m.

${ }^{9}$ Niwelety poszczególnych kamieni oscylowały wokół wartości 62,65-62,7 m n.p.m. Rozstaw i położenie kamieni wskazywały na technikę stawiania danej ściany budynku.
} 


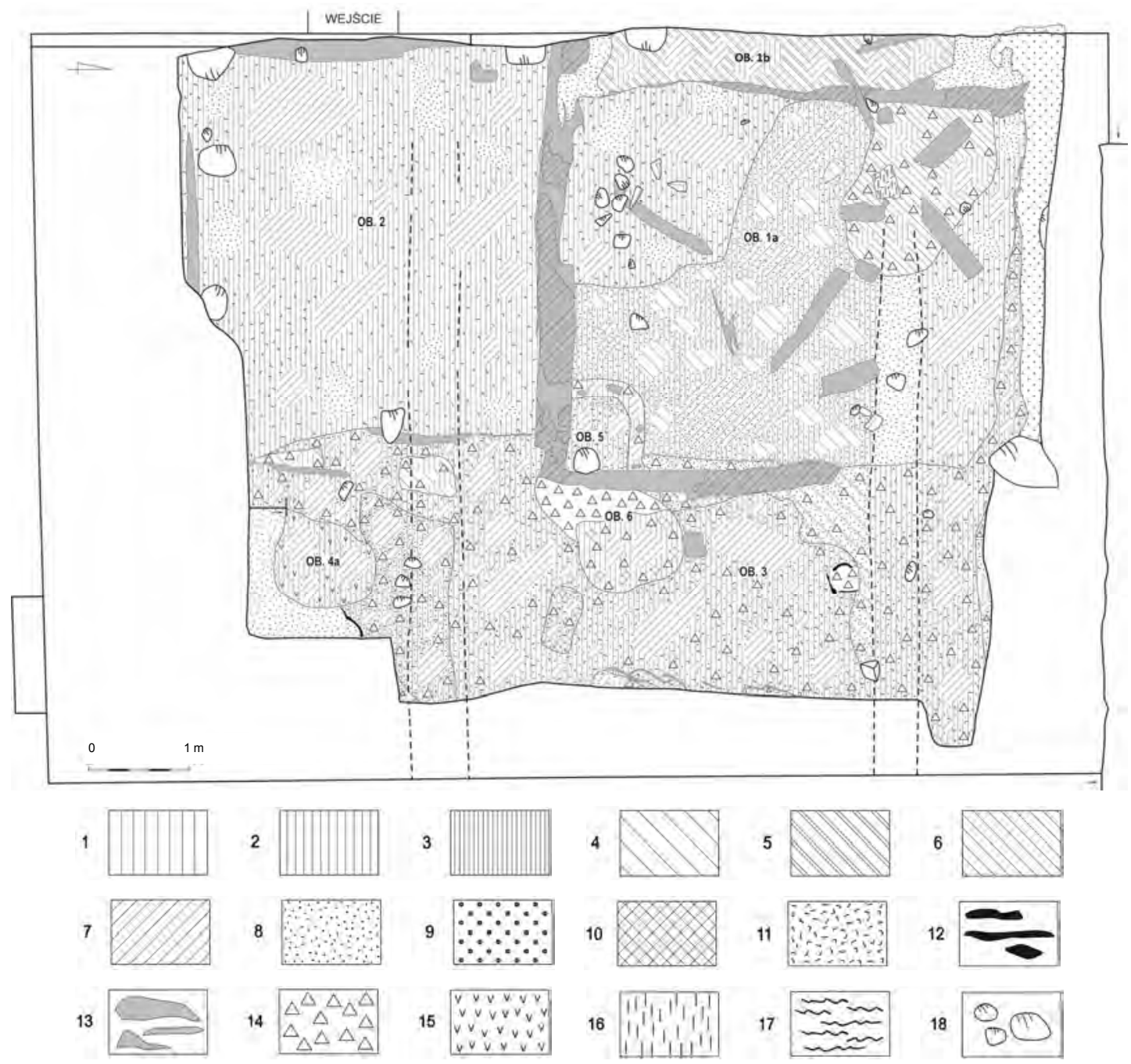

Legenda (opis warstw - dotyczy również rycin 9 i 10)

1. próchnica jasnoszara, 2. próchnica szara, 3. próchnica ciemnoszara, 4. glina żółta, 5. glina oliwkowożółta, 6. glina oliwkowa, 7. glina szara, 8. piasek, 9. piasek calcowy, 10. spalenizna, 11. węgle drzewne, 12. drewno spalone, 13. drewno zbutwiałe, 14. polepa, 15. zaprawa wapienna, 16. popiół, 17. mierzwa, 18. kamienie

Legend (description of the layers - also for figures 9 and 10)

1. light-grey humus, 2. grey humus, 3. dark-grey humus, 4. yellow clay, 5. olive-yellow clay, 6. olive clay, 7. grey clay, 8. sand, 9 . bedrock sand, 10. fired layer, 11. charcoals, 12. burned wood, 13. decayed wood, 14. daub, 15. lime mortar, 16. ash, 17. mulch, 18. stones

Ryc. 6. Mosina, gm. loco, Plac 20 Października nr 7. Badania archeologiczne, 2011 r. Relikty zabudowy w wykopie nr I, poziom 62,52-62,8 m n.p.m. (rys. J. Kędelska, E. Pawlak)

Fig. 6. Mosina, com. loco, Plac 20 Października No. 7. Archaeological excavations in 2011. Relics of buildings, level 62.52-62.8 m a.s.l. (by J. Kędelska, E. Pawlak) 
W południowo-wschodnim narożu północnej izby przedniej omawianego domu odkryto zarysy fundamentów pieca kaflowego o wymiarach $0,9 \times 0,7 \mathrm{~m} \mathrm{z}$ reliktami glinianych, mocno rozlasowanych ścianek o grubości 0,15/0,18 m (obiekt nr 5). $\mathrm{Z}$ gruzowiska pieca wydobyto liczne, acz mocno rozdrobnione ułamki kafli płytowych i miskowych, fragmenty okopconych cegieł, dachówek, płytek ceramicznych oraz grudy gliny konstrukcyjnej, ponadto ułamki naczyń glinianych i kości zwierzęcych. Rozsypisko pieca, obserwowane również na niższym poziomie, „ułożyło się” wzdłuż wschodniej ściany pomieszczenia na odcinku o długości ok. 2,7 m i szerokości ok. 0,9/1,4 m. Po przeciwległej stronie pieca, w narożu północno-zachodnim, odnotowano pozostałości bliżej nieokreślonej pod względem funkcjonalnym konstrukcji z ułożonych „,na krzyż” belek o długości od 0,6 do 1,2 m i szerokości ok. 0,2 m. Pośrodku, między ramionami „krzyża” zlokalizowano dół posłupowy o wymiarach $0,2 \times 0,3 \mathrm{~m} \mathrm{z}$ pozostałościami spalonego słupa. Wokół słupa i między belkami zalegała warstwa gliny o barwie oliwkowej, przemieszanej z grudkami polepy i szarą, zglinioną próchnicą, zdecydowanie różniącą się od reszty wypełniska w pomieszczeniu, tj. szarej, zglinionej próchnicy z plamami żółtego piasku i gliny. Bez bliższego określenia funkcjonalnego pozostało także niewielkie skupisko kamieni i resztek zbutwiałych belek w otoczce szarej, zglinionej próchnicy z plamami żółtego piasku, gliny i licznych węgli drzewnych, zarejestrowane nieopodal południowo-zachodniego naroża izby (ryc. 6).

Wypełniska dwóch pozostałych pomieszczeń były w miarę jednorodne, w izbie tylnej zaobserwowano oliwkowo-brązową glinę przemieszaną z szarą, zglinioną próchnicą ${ }^{10}$, a południowej przedniej - szarą, zglinioną próchnicę z plamami żółtego piasku, gliny i licznymi węglami drzewnymi (ryc. 6).

Fragmenty wydobytych kafli i naczyń glinianych wyraźnie wskazały na późnonowożytną proweniencję domostwa. Rozsypisko pieca przyniosło m.in. bardzo charakterystyczne dla ok. połowy XVII stulecia egzemplarze kafli płytowych z motywami roślinnymi, architektonicznymi, geometrycznymi. Szczególnie interesujące okazały się egzemplarze ozdobione czteropolowymi kasetonami (ryc. 7:1) oraz palmetami (ryc. 7:3), analogiczne do kafli znalezionych w końcu lat 80. minionego wieku w pobliskim Krajkowie i podobnie datowanych (Łaszkiewicz 1997, tab. 13:1, 30:1). Wymiary płyt mieściły się w granicach $18 \times 19 \times 1 \mathrm{~cm}$, wysokość kołnierzy wynosiła ok. $6,5 \mathrm{~cm}$, z płytą dany kafel był wysoki na ok. 7,5 cm. Tylko część z tych kafli była pokryta szkliwem zielonym i pobiałą. Zbioru dopełniły stosunkowo niewielkie okazy miskowe z kwadratowymi wylotami o boku długości 16,5 cm i wysokości 11,5 cm, niepolewane, niekiedy pobielane od wewnątrz (ryc. 7:4-6). Liczba znalezionych kafli nie pozwoliła na odtworzenie wyglądu pieca, niemniej można sądzić, iż była to konstrukcja dwuskrzyniowa, z częścią dolną zbudowaną z kafli płytowych i górną - z miskowych, żywo przypominająca rozwiązania stosowane już kilkadziesiąt lat wcześniej w niedalekim Poznaniu (Wawrzyniak 2003, s. 201, ryc. 11).

\footnotetext{
${ }^{10}$ Ze względów bezpieczeństwa zakończono dalszą eksplorację obiektu nr 1b na tym poziomie.
} 

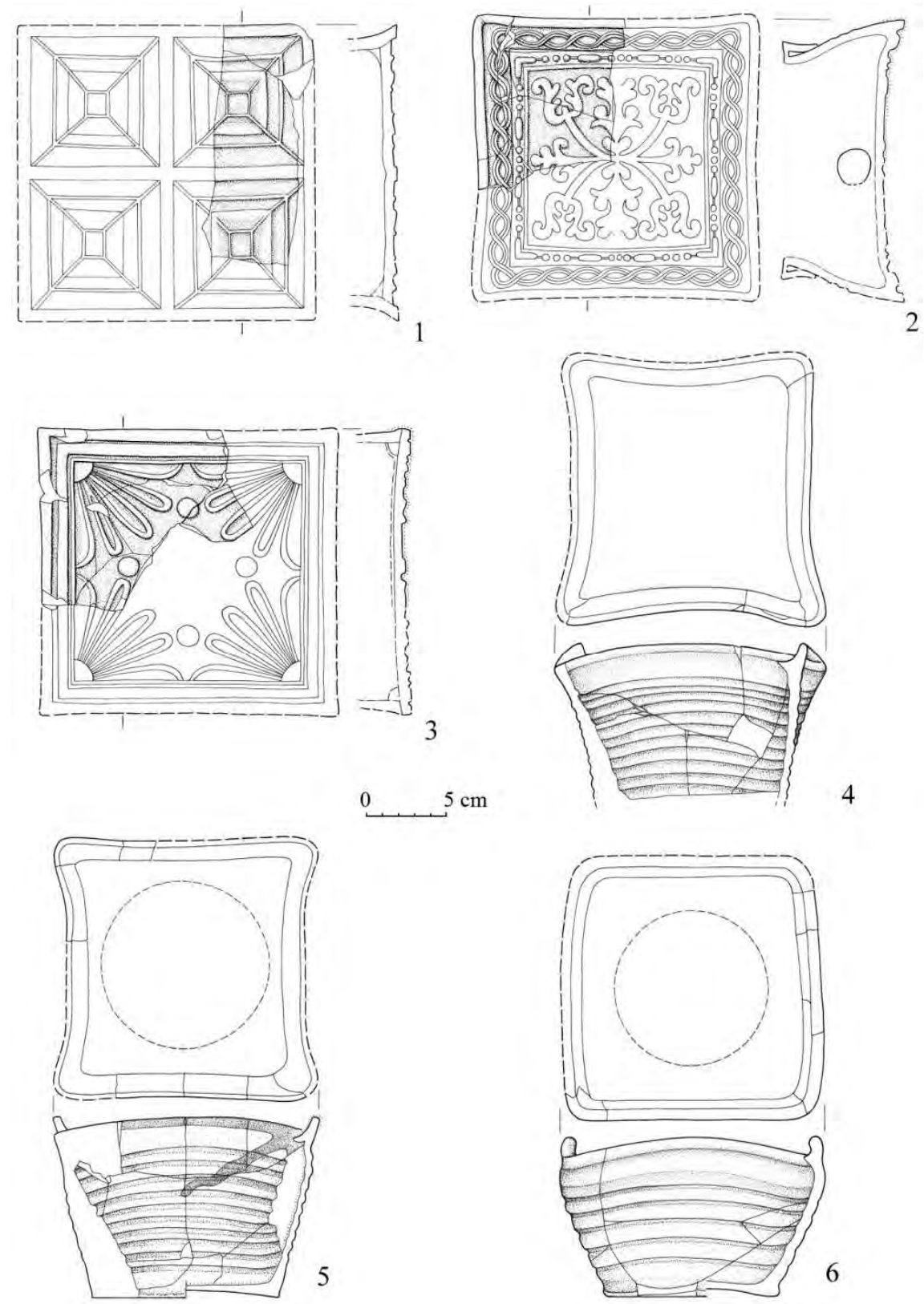

Ryc. 7. Mosina, gm. loco, Plac 20 Października nr 7. Badania archeologiczne, 2011 r. Wykop nr I. Wybór kafli płytowych i miskowych wydobytych $\mathrm{z}$ rumowiska pieca zlokalizowanego $\mathrm{w}$ domu nowożytnym (rys. J. Beda, J. Kędelska)

Fig. 7. Mosina, com. loco, Plac 20 Października No. 7. Archaeological excavations in 2011. Trench No. I. Selection of plate and bowl stove tiles collected from a debris of a stove (feature No. 5) within a modern house (by J. Beda, J. Kędelska) 

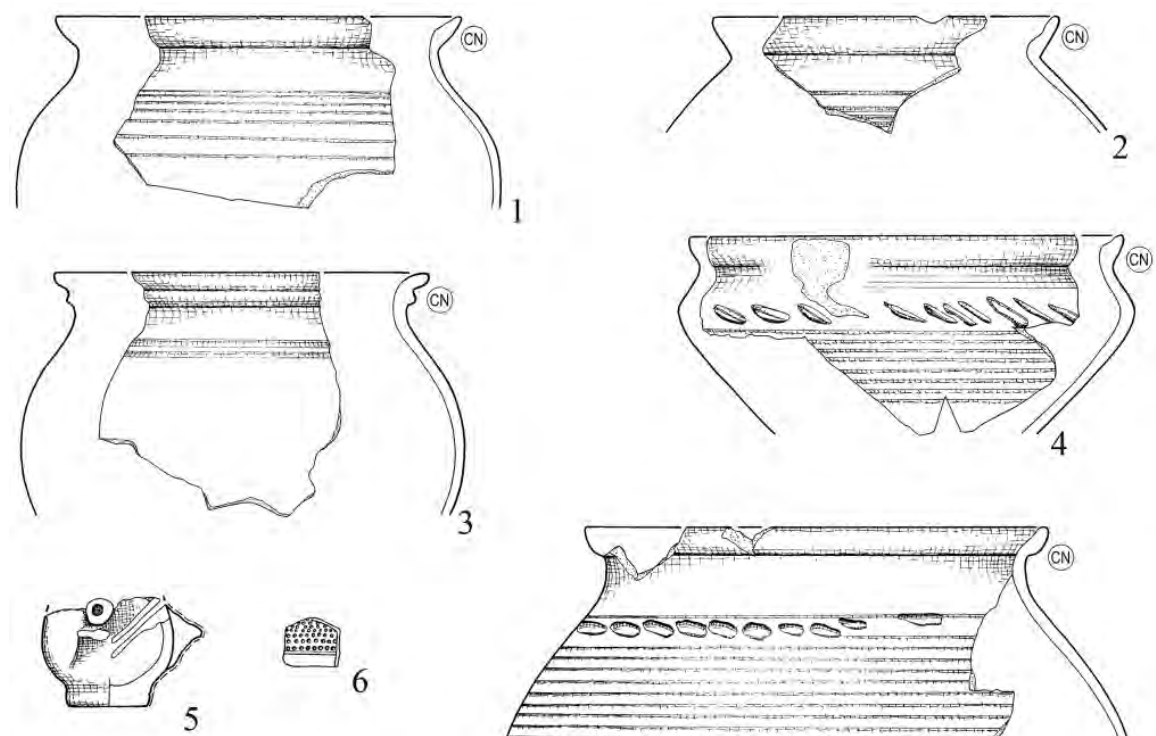

\section{6}
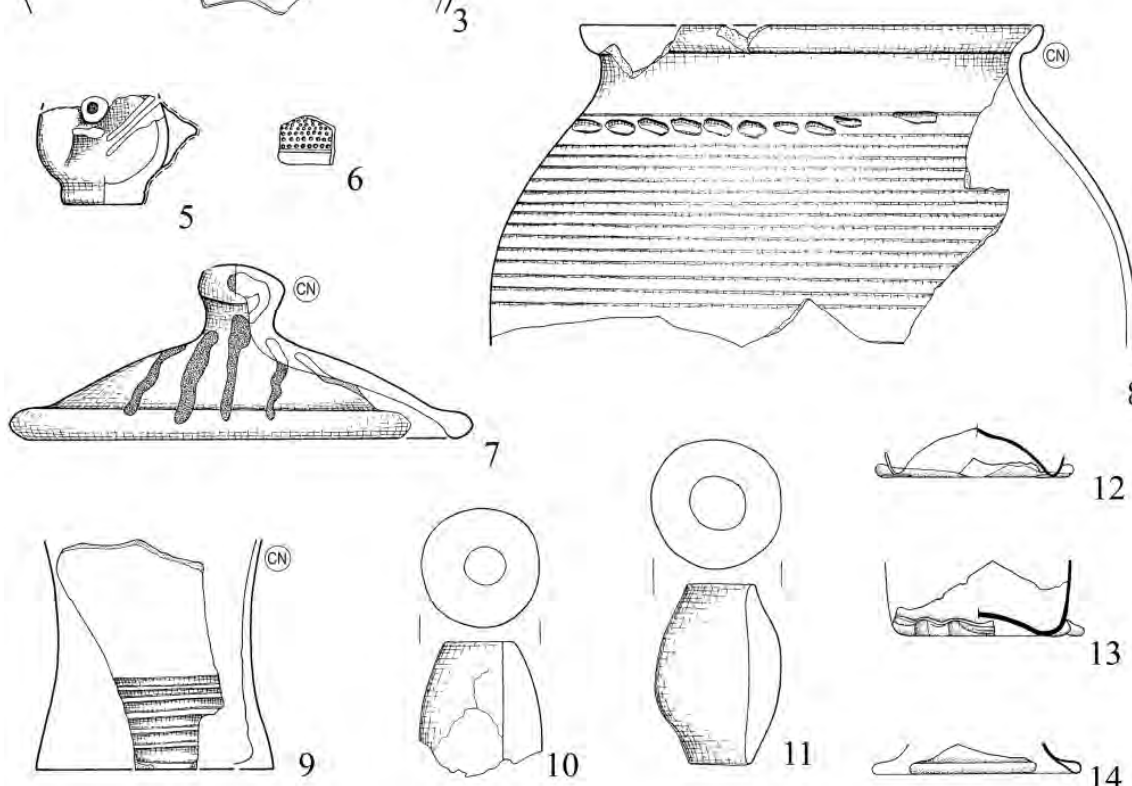

8

12

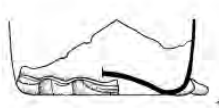

13

11
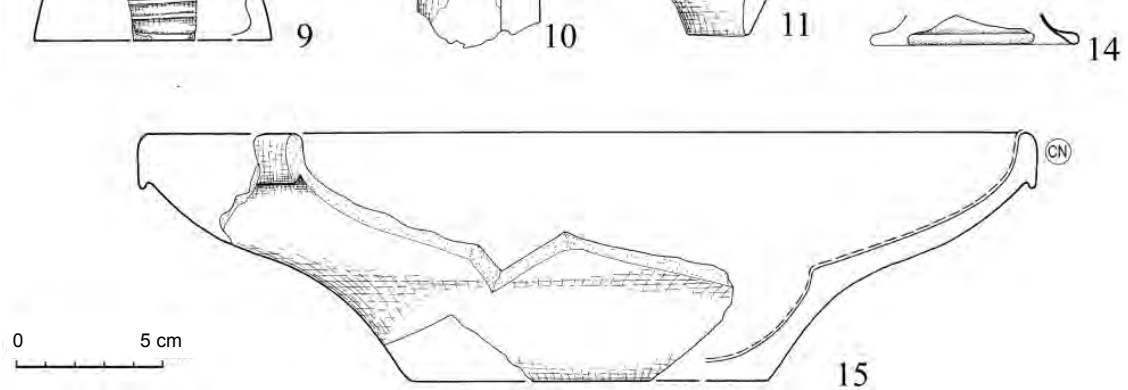

Ryc. 8. Mosina, gm. loco, Plac 20 Października nr 7. Badania archeologiczne, 2011 r. Wykop nr I. Wybór ruchomego materiału źródłowego z północnego pomieszczenia przedniego domu nowożytnego (B - ceramika brunatna, S - stalowoszara, CN - nowożytna) (rys. J. Beda, J. Kędelska)

Fig. 8. Mosina, com. loco, Plac 20 Października No. 7. Archaeological excavations in 2011. Trench No. I. Selection of artefacts from northern room of a front modern house (B - brown pottery, $\mathrm{S}$ - steel-gray pottery, $\mathrm{CN}$ - modern pottery) (by J. Beda, J. Kędelska) 
Znaczne rozdrobnienie uniemożliwiło rekonstrukcję całych form naczyń. Wydzielono jednak całą serię szerokootworowych wylewów garnków jajowatych i baniastych o średnicach od 12 do $16 \mathrm{~cm}$ (ryc. 8:1-3, 8), a więc z asortymentu naczyń średnich i dużych, ponadto ułamki trójnóżków - patelni oraz rynienek - przynależne do kategorii pojemników kuchennych, a także fragmenty naczyń wazowatych (?), mis, talerzy, kubków (?), pucharków, dzbanów (ryc. 8:4, 9, 15) z kategorii naczyń stołowych. Natrafiono również na kilkanaście ułamków pokrywek, w tym malowanych pobiałą (ryc. 8:7). Dominowała starannie wykonana, toczona i cienkościenna ceramika wypalona w atmosferze utleniającej, ceglasta lub „pseudomajolikowa”, nader oszczędnie zdobiona, najczęściej żłobkami dookolnymi, dołkami paznokciowymi, delikatnymi listwami plastycznymi bądź malaturą. Szkliwo stosowano bardzo rzadko, przede wszystkim polewano nim wewnętrzne, wcześniej pokryte pobiałą,

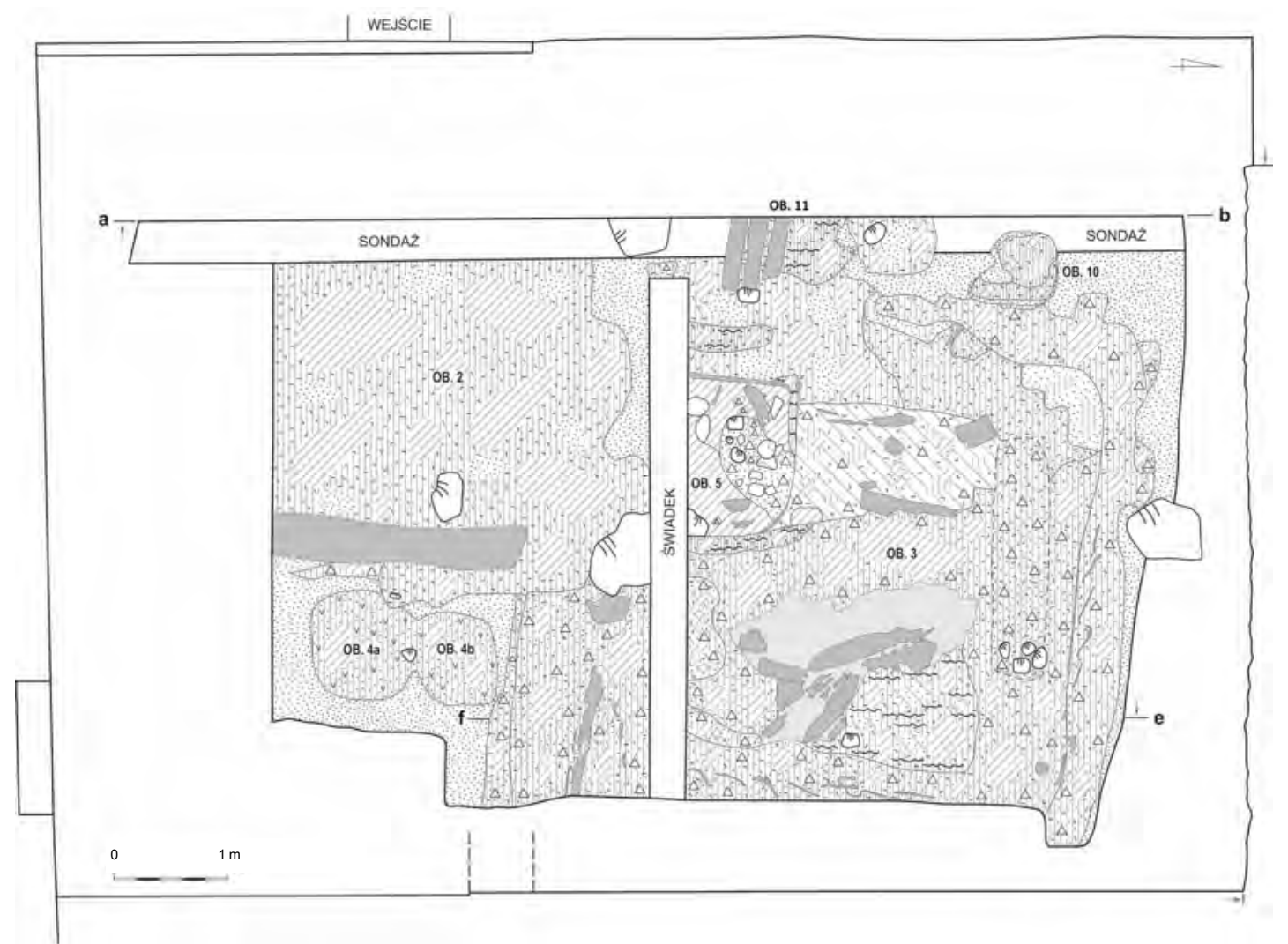

Ryc. 9. Mosina, gm. loco, Plac 20 Października nr 7. Badania archeologiczne, 2011 r. Relikty zabudowy w wykopie nr I, poziom 62,45-62,7 m n.p.m. (rys. J. Kędelska, E. Pawlak)

Fig. 9. Mosina, com. loco, Plac 20 Października No. 7. Archaeological excavations in 2011. Relics of a building in trench No. I, level 62.45-62.7 m a.s.1. (by J. Kędelska, E. Pawlak) 
powierzchnie talerzy i mis „pseudomajolikowych”. Wstępnie określono powyższy materiał ceramiczny jako pochodzący z pierwszej połowy XVIII w., aczkolwiek nie należy wykluczyć okazów wcześniejszych, nawet z ok. połowy XVII stulecia.

Omawiany inwentarz ceramiczny uzupełniły m.in. ułamki partii przydennych kilku naczyń szklanych (ryc. 8:12-14) i drobne przedmioty codziennego użytku, w tym przęśliki gliniane (ryc. 8:10-11) oraz niewielki, miedziany (?) naparstek (ryc. 8:6). Znaleziono nawet figurkę glinianego ptaszka - gwizdawkę, niestety zachowaną fragmentarycznie (ryc. 8:5).

Z nawarstwień domostwa wydobyto także znaczne ilości ceramiki późnośredniowiecznej, wstępnie datowanej na drugą ćwierć XV stulecia. Zalegała ona na złożu wtórnym. Część tego materiału zapewne pochodziła $\mathrm{z}$ wypełniska średniowiecznego domu, którego partię zachodnią zarejestrowano bezpośrednio pod reliktatami północnego pomieszczenia przedniego budynku nowożytnego. W sąsiednim, południowym pomieszczeniu frontowym tegoż budynku udział ceramiki XV-wiecznej, głównie stalowoszarej, wyniósł prawie 38\% całości zbioru (ryc. 11:1-4, 7). Sądzimy, iż jest to jedyny, namacalny ślad po znajdującej się onegdaj w tym miejscu starszej konstrukcji, która uległa całkowitemu zniesieniu na skutek późniejszych działań budowlanych.

Mocno zniszczone nowożytnymi, a nawet współczesnymi wkopami ${ }^{11}$ relikty domu średniowiecznego (obiekt nr 3) odnotowano w części północnej wykopu na poziomie $62,59 / 62,57-62,51 / 62,43 \mathrm{~m}$ n.p.m. Było to jednoizbowe założenie mieszkalne o wymiarach $4,2 \times 4 \mathrm{~m}$ i froncie przebiegającym w odległości ok. 1,5 m od obecnej linii zabudowy rynku. Dom wzniesiono prawdopodobnie w technice „na zrąb" w wykopie o przypuszczalnej głębokości $0,95 \mathrm{~m}$. Ściany budowli wzmocniono od zewnątrz pionowo ustawionymi dranicami, po których zachowały się w kilku miejscach charakterystyczne zaciemnienia złożone z silnie spiaszczonej, jasnoszarej próchnicy, przypominające ślady po plecionym płocie. Wejście do budynku (obiekt nr 11) prowadziło od podwórza, czyli od strony zachodniej. Wewnątrz, w części wschodniej pomieszczenia, wypreparowano na poziomie 62,56-62,54 m n.p.m. centymetrową warstewkę zbutwiałego drewna, przypuszczalnie relikt podłogi (ryc. 9). Wypełnisko obiektu o miąższości ok. 0,35/0,45 m, mocno przemieszane w partii stropowej, niżej, na poziomie 62,43-62,41 m n.p.m., było już jednorodne i zostało opisane jako ciemnoszara, zgliniona próchnica $\mathrm{z}$ dużą ilością węgli drzewnych oraz fragmentami spalonych bądź zbutwiałych, bezładnie rozrzuconych belek. Przy ścianach południowej i zachodniej założenia odnotowano kilkanaście niewielkich dołków posłupowych lub jam o średnicach $0,25-0,3 \mathrm{~m}$ i głębokości dochodzącej do $0,2 \mathrm{~m}$ (obiekty $\mathrm{nr} 7-10,15-19)$. Zapewne były one funkcjonalnie powiązane $\mathrm{z}$ konstrukcjami tychże ścian. Kolejne dwa dołki (obiekty nr 12 i 14) wydzielono we wnętrzu

\footnotetext{
${ }^{11}$ Jeden z tych wkopów z pozostałościami ławy fundamentowej pod mur działowy, dzielący onegdaj badane pomieszczenie na mniejsze lokalności, oznaczono jako obiekt nr 13.
} 


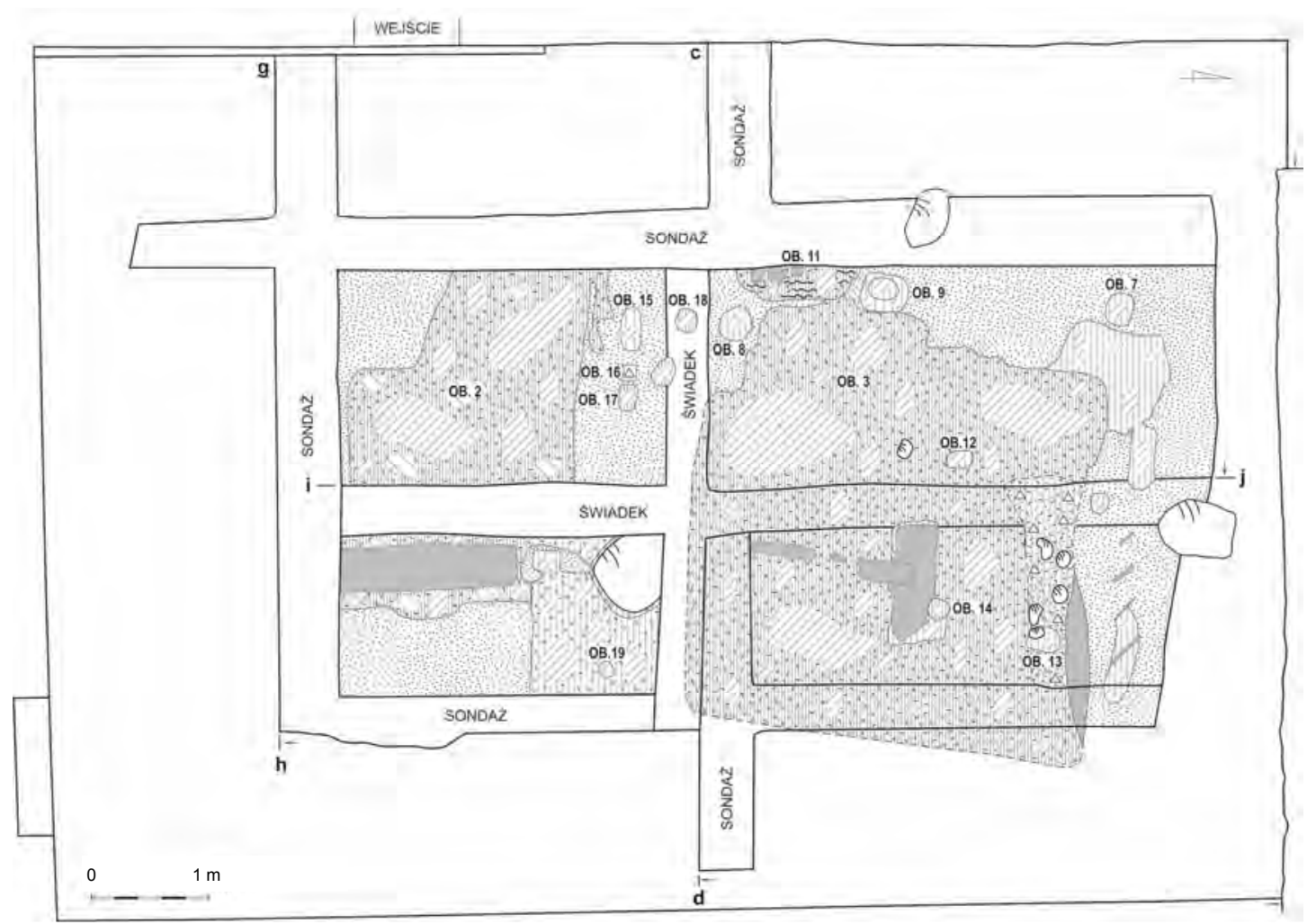

Ryc. 10. Mosina, gm. loco, Plac 20 Października nr 7. Badania archeologiczne, 2011 r. Relikty zabudowy w wykopie nr I, poziom 62,14-62,53 m n.p.m. (rys. Ł. Gil, J. Kędelska, E. Pawlak)

Fig. 10. Mosina, com. loco, Plac 20 Października No. 7. Archaeological excavations in 2011. Relics of a building in trench No. I, level 62.14-62.53 m a.s.1. (by Ł. Gil, J. Kędelska, E. Pawlak)

domu. Ich funkcja pozostała nieokreślona (ryc. 10). Spąg wypełniska obiektu nr 3 uchwycono na poziomie ok. 62,10 m n.p.m. Niżej zalegał calec - żółty, drobnoziarnisty piasek pochodzenia rzecznego.

Eksploracja opisanego wyżej rozwaliska przyniosła, oprócz kilku drobnych przedmiotów codziennego użytku (ryc. 12:1, 3, 5), zbiór ponad 1200 fragmentów naczyń glinianych, głównie stalowoszarych ( $88,9 \%$ całości zbioru), a więc poddanych podczas wypału zabiegowi redukcji. Wśród pozostałych, wypalonych w atmosferze utleniającej, rozpoznano kilkadziesiąt ułamków ceramiki ceglastej - nowożytnej, która najpewniej dostała się tutaj przypadkowo, prawdopodobnie w trakcie budowy i późniejszego użytkowania domu XVII-wiecznego, a także niewielki zespół ceramiki brunatnej, stylistycznie i technologicznie zbliżonej do materiałów ceramicznych wczesnośredniowiecznych. 

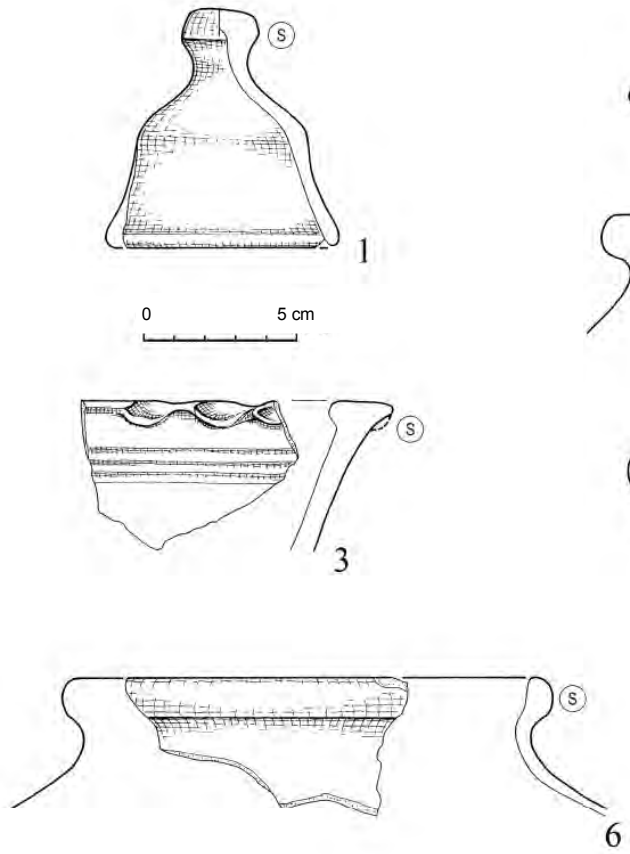

6
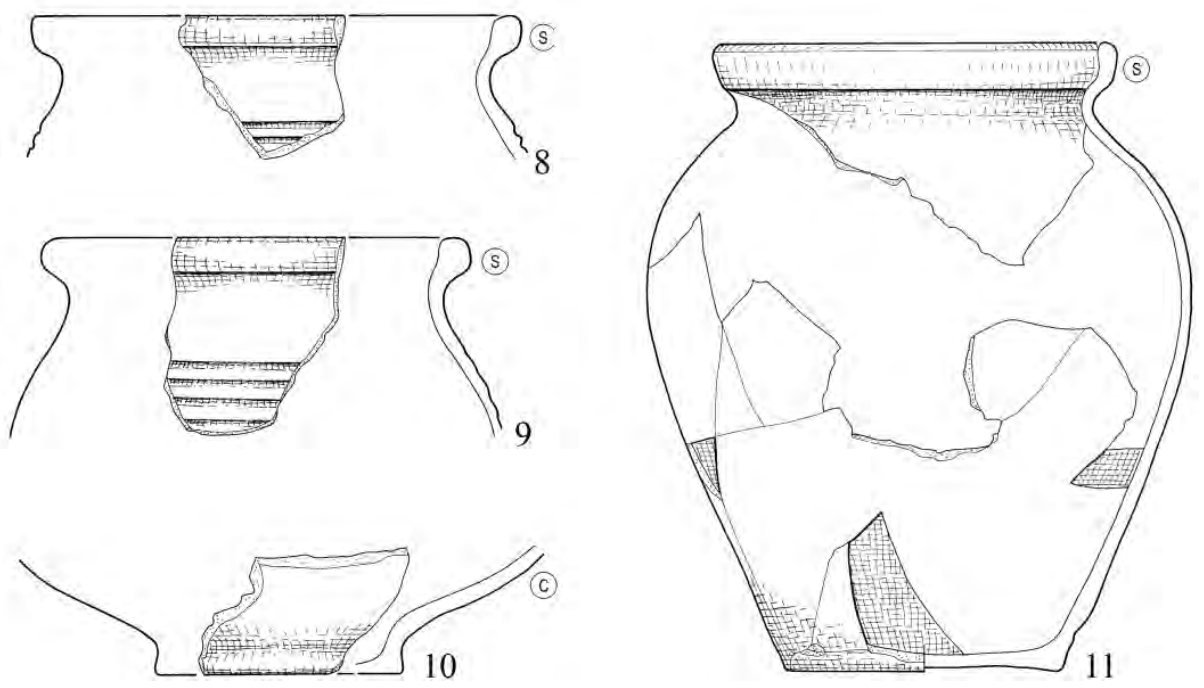

Ryc. 11. Mosina, gm. loco, Plac 20 Października nr 7. Badania archeologiczne, 2011 r. Wykop nr I. Wybór ruchomego materiału źródłowego $\mathrm{z}$ południowego pomieszczenia przedniego domu nowożytnego $(1-4,7)$ i domu średniowiecznego (5-6, 8-11) (rys. J. Beda, J. Kędelska)

Fig. 11. Mosina, com. loco, Plac 20 Października No. 7. Archaeological excavations in 2011. Trench No. I. Selection of artefacts from southern room of a front modern house $(1-4,7)$ and medieval house $(5-6$, 8-11) (by J. Beda, J. Kędelska) 
Cechą charakterystyczną badanej ceramiki była jej wysoka jakość, cienkościenność i jednorodność. Do wyrobu naczyń używano wyłącznie glin żelazistych, które schudzano najczęściej drobno- i średnioziarnistym piaskiem, sporadycznie drobnym tłuczniem. Ilość dodawanej do masy ceramicznej domieszki mineralnej była stosunkowo niewielka, co najwyżej średnia. Naczynia lepiono metodą ślizgowo-taśmową, a następnie silnie obtaczano na szybkoobrotowym kole garncarskim. Wydaje się, że mniejsze formy, np. pucharki, czarki wytaczano na kole z jednego kęsa gliny, po czym gotowy egzemplarz odcinano od jego powierzchni za pomocą sznurka lub drutu, uzyskując charakterystyczny rysunek ,pętli”. Ślady odcinania stwierdzono także na dnach innych naczyń, podobnie jak stosowanie, chociaż znacznie rzadsze, podsypki drobnoziarnistego piasku. Niekiedy powierzchnie den zagładzano bądź podważano nożem ich krawędzie, w kilku przypadkach odnotowano obecność pierścienia dookolnego, także wśród pojemników o dnach „odcinanych”. Dobrą jakość wypału potwierdziły obserwacje barw powierzchni czerepów i przełamów ceramiki, $\mathrm{z}$ reguly jednolite.

Tylko jeden fragment naczynia - stalowoszarego - pokryto, od strony wewnętrznej, przezroczystym szkliwem.

Zdobienia, chociaż liczne, ograniczone są do kilku podstawowych technik i motywów. Przede wszystkim stosowano ornament ryty. Jego najczęstszą odmianą były zwielokrotnione, szerokie żłobki dookolne, płytkie i o zaokrąglonych krawędziach, które kładziono od partii przydennej po największą wydętość brzuśca danego naczynia (ryc. 11: 8-9; 12:13; 13:10). Równie często rejestrowano pojedyncze lub co najwyżej kilkakrotnie zdwojone żłobki dookolne, ostro profilowane, wąskie i głębokie, które umieszczano $\mathrm{w}$ miejscach podkreślających tektonikę pojemnika - pod krawędzią, na największej wydętości brzuśca czy też w partii przydennej (ryc. 11:3, 12:6-7; 13:1). Motyw dookolnej linii falistej stwierdzono tylko w kilku przypadkach (ryc. 11:7). Niezmiernie rzadko stosowano ornament radełkowy (ryc. 13:2) i plastyczny (ryc. 11:3; 12:8; 13:2, 11). Zabiegiem wyświecania potraktowano tylko zewnętrzne powierzchnie pucharków (ryc. 12:6-8) i czarek (ryc. 12:9).

Asortyment naczyń z obiektu nr 3 okazał się typowy dla schyłku późnego średniowiecza. Wydzielono zatem zestaw pojemników kuchennych i magazynowych, w tym szerokootworowe garnki jajowate bądź baniaste o średnicach wylewów od 12 do $18 \mathrm{~cm}$, ponadto misy z zaobserwowanymi na powierzchniach wewnętrznych śladami ucierania potraw oraz duże dzbany o cylindrycznych szyjach, zaopatrzone w szerokie, taśmowate ucha (ryc. 11:5-6, 8-9, 11; 12:14; 13), i stołowych, tj. dzbany o mniejszych rozmiarach, naczynia misowate, czarki, pucharki, kubki (ryc. 11:10; 12:6-13,15). Ponadto zarejestrowano kilkanaście okazów pokrywek dzwonowatych i kloszowatych, w tym egzemplarz zachowany niemal w całości, dzwonowaty, o wysokości 6,5 i średnicy wylewu 13,5 cm (ryc. 12:2). Drugą ze zrekonstruowanych w całości form okazał się średniej wielkości, cienkościenny garnek jajowaty o wysokości 20,5, średnicy wylewu 12,5 i dna $9 \mathrm{~cm}$. Mocno pogrubioną krawędź wy- 

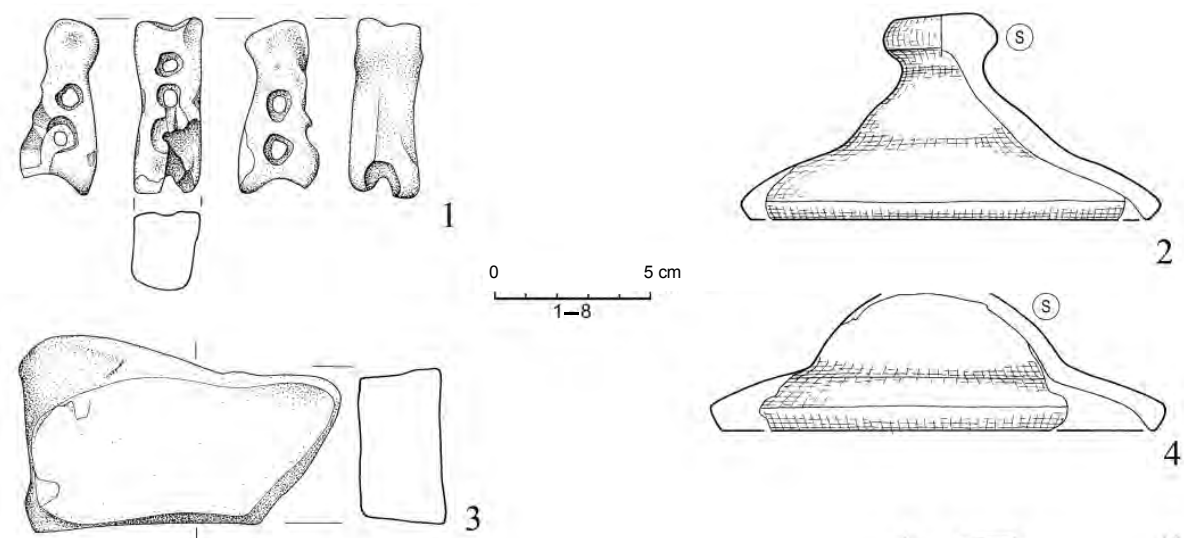

3
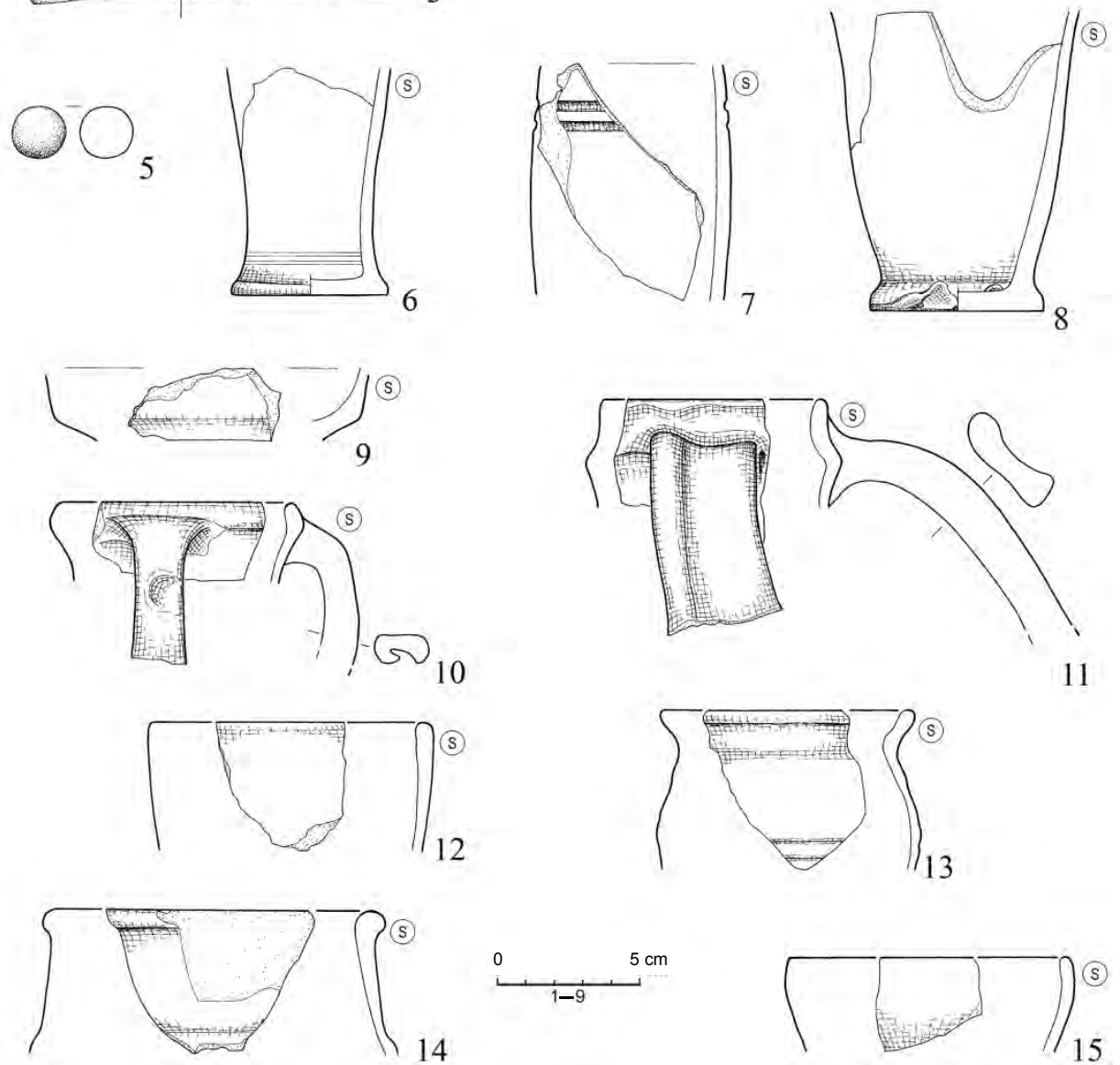

Ryc. 12. Mosina, gm. loco, Plac 20 Października nr 7. Badania archeologiczne, $2011 \mathrm{r}$. Wykop nr I. Wybór ruchomego materiału źródłowego z domu średniowiecznego (rys. J. Beda, J. Kędelska)

Fig. 12. Mosina, com. loco, Plac 20 Października No. 7. Archaeological excavations in 2011. Trench No. I. Selection of artefacts from medieval house (by J. Beda, J. Kędelska) 

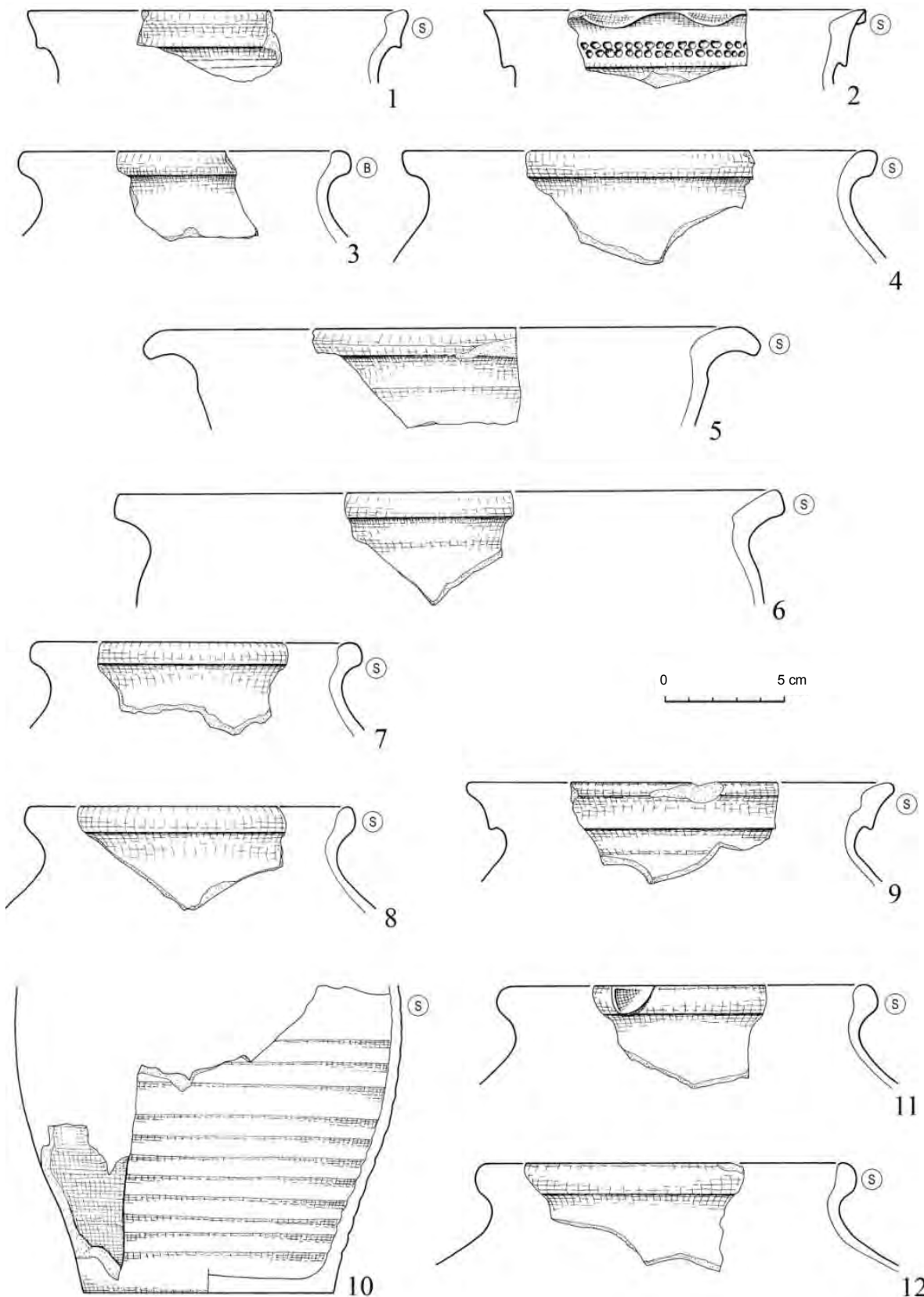

Ryc. 13. Mosina, gm. loco, Plac 20 Października nr 7. Badania archeologiczne, 2011 r. Wykop nr I. Wybór ruchomego materiału źródłowego z domu średniowiecznego (rys. J. Beda, J. Kędelska)

Fig. 13. Mosina, com. loco, Plac 20 Października No. 7. Archaeological excavations in 2011. Trench No. I. Selection of artefacts from medieval house (by J. Beda, J. Kędelska) 
lewu tego pojemnika zaopatrzono we wręb na pokrywkę, na powierzchni jego dna zaobserwowano zaś charakterystyczne ślady „odcinania”(ryc. 11:11). Niemal w całości zachował się jeden z pucharków o wyświeconej powierzchni zewnętrznej i charakterystycznie „szczypanej” krawędzi dna (ryc. 12:8).

Przedstawiony wyżej zespół ceramiki wstępnie wydatowano na drugą ćwierć XV w.

Założony na tyłach posesji wykop sondażowy nr III nie przyniósł większych rezultatów. Pod współczesnymi nawarstwieniami gruzowo-próchnicznymi zarejestrowano ciemnobrunatną próchnicę o miąższości około $0,6 \mathrm{~m} \mathrm{z}$ nielicznymi ułamkami średniowiecznych naczyń stalowoszarych i nowożytnych, ceglastych oraz kamionkowych, a niżej, na głębokości około 1,45 m, strop calca - ciężką, zwałową glinę barwy żółto-brązowej. Warstwa zalegającej nad calcem próchnicy sprawiała wrażenie onegdaj uprawianej.

\section{$* * *$}

Prace wykopaliskowe z wiosny 2011 r. na parceli przyrynkowej nr 7 przy Placu 20 Października były pierwszymi w historii Mosiny szerokopłaszczyznowymi badaniami dawnej mieszkalnej tkanki miejskiej ${ }^{12}$. Rozpoznano dwa poziomy (XVi XVII/XVIII-wieczny) reliktów dawnej zabudowy, zlokalizowanej w partii frontowej działki usytuowanej w pierzei zachodniej mosińskiego rynku. Wziemne partie budynków, być może podcieniowych ${ }^{13}$, zlokalizowano w odległości ok. 1,5-3,5/3,9 m od obecnej elewacji frontowej domu. Dalszej zabudowy i sposobu zagospodarowania działki nie uchwycono, nieznana pozostała również głębokość założenia nowożytnego. Stwierdzono jedynie, że na tyłach działki uprawiano rolę bądź był urządzony ogród, zapewne warzywny (por. też Baranowski 1971, s. 85-86).

Materiałem datującym okazała się ceramika: stalowoszara dla zespołu XV-wiecznego i ceglasta bądź ,pseudomajolikowa” dla zbioru XVII- i XVIII-wiecznego. Nie zarejestrowano materiałów z XIII i XIV stulecia.

Uderzająca nieobecność materiałów z głębokiego średniowiecza (także z wcześniejszych badań) przemawia na korzyść postawionej we wstępie niniejszego artykułu propozycji badawczej o ewentualnej translokacji Mosiny z terenów Niwki w początkach drugiej ćwierci XV stulecia, tj. w momencie wystawienia nowego

\footnotetext{
${ }^{12}$ Oprócz nadzoru nad budową nitki rurociągu przebiegającej w pobliżu rynku, przeprowadzonego w 2002 r., kiedy to w sześciu sondażach natrafiono na pozostałości moszczeń ulic i relikty nowożytnej zabudowy mieszkalnej z XVI-XVIII w. (Pawlak E., Pawlak P. 2014, s. 249; tam dalsza literatura).

${ }^{13} \mathrm{O}$ czym pośrednio świadczy pusta przestrzeń między frontami dawnych budynków a obecną linią zabudowy, pierwotnie prawdopodobnie zajmowana przez podcienia. Takie rozwiązania, dzisiaj niezmiernie rzadkie, były powszechne w miasteczkach Wielkopolski jeszcze w XVIII i początkach XIX stulecia (zob. np. ryciny XVIII-wiecznych domów podcieniowych zamieszczonych w: Baranowski 1971). Pojedyncze, drewniane domy podcieniowe zachowały się jeszcze w kilku miastach Wielkopolski, m.in. w pobliskim Stęszewie.
} 
przywileju lokacyjnego przez Władysława Jagiełłę. Powtórzmy zatem raz jeszcze, że być może pierwotnie Mosinę ulokowano w Niwce, zapewne w rejonie dzisiejszej przeprawy mostowej i oczyszczalni ścieków - gdzie przeszło 25 lat temu odkryto rozległą osadę z przełomu XIII i XIV w. ${ }^{14}$ - a po dwóch wiekach decyzją królewską przeniesiono $\mathrm{w}$ obecne miejsce. Udowodnienie tej hipotezy wymaga jednak dalszych studiów archiwalnych i gabinetowych, w tym dogłębnego opracowania oraz opublikowania wyników prac wykopaliskowych wzmiankowanej wyżej osady i wreszcie: interdyscyplinarnych badań archeologicznych historycznego centrum miasta.

\section{Poznań, 29 czerwca $2014 \mathrm{r}$.}

\section{BIBLIOGRAFIA}

Baranowski B.

1971 Kultura ludowa XVII i XVIII w. na ziemiach Polski Środkowej. Łódź: Wydawnictwo Łódzkie.

Gazeta Mosińsko-Puszczykowska

2012 [pobrane z: www.gazeta-mosina.pl].

Gąsiorowski A. (red.)

1999 Stownik geograficzno-historyczny województwa poznańskiego w średniowieczu (cz. III, z. 4, Pniewy - Q). Poznań: Wydawnictwo PTPN.

Górczak Z.

$2002 \quad$ Najstarsze lokacje miejskie w Wielkopolsce (do 1314 roku). Poznań: Wydawnictwo Wojewódzkiej Biblioteki Publicznej i Centrum Animacji Kultury.

Habdas R.

1987 Mały Paryż. Ziemia Mosińska, 11(1987).

Kodeks Dyplomatyczny Wielkopolski

$1878 \quad$ (t. 2, wyd. I., Zakrzewski) Poznań.

Krzyszowski A.

1992 Wstępne wyniki badań archeologicznych na wczesnośredniowiecznym cmentarzysku szkieletowym z X/XI-XI wieku w miejscowości Sowinki, gm. Mosina, woj. poznańskie, stanowisko 23A. Wielkopolskie Sprawozdania Archeologiczne, 1, s. 83-102.

Kruppé J.

1983 „Indagandy” o stanie garncarstwa miejskiego Wielkopolski w końcu XVIII wieku. W: Z. Kamieńska (red.), Wybrane problemy kultury materialnej miast polskich w XVIII i XIX wieku (t. LVI, s. 133-191). Wrocław: Zakład Narodowy im. Ossolińskich.

Łaszkiewicz A.

1997 Kafle i piece kaflowe z dworu na kopcu w Krajkowie pod Mosina, woj. poznańskie (Biblioteka Wielkopolskich Sprawozdań Archeologicznych, t. 1). Poznań: Stowarzyszenie Naukowe Archeologów Polskich.

\footnotetext{
${ }^{14}$ Niestety materiały $z$ tych badań, opracowane częściowo, nie zostały opublikowane. Stawiana wówczas hipoteza, że natrafiono na relikty nieistniejącej wsi Przewóz, nie została potwierdzona przez historyków, którzy opowiadają się za lokalizacją tejże wsi na prawym brzegu Warty, ok. 0,5 km na północny zachód od miejscowości Trzykolne Młyny (Gąsiorowski 1999, s. 872, przyp. 1).
} 
Łojko J., Stępień J.

1992 Zarys dziejów Mosiny i okolic. Mosina: Wydawnictwo „Alpim”.

Łukaszewicz J.

1858 Krótki opis historyczny kościołów parochialnych, kościótków, kaplic, klasztorów, szkółek parochialnych, szpitali i innych zakładów dobroczynnych $w$ dawnej dyecezyi poznańskiej (t. I). Poznań.

Łęcki W. (red.)

2002 Mosina. 700 lat. Warszawa-Poznań-Mosina: Wydawnictwo API-Press.

Pasek J. Ch.

2006 Pamiętniki. Warszawa: Wydawnictwo Orkla Press Polska Sp. z o.o.

Pawlak E., Pawlak P.

2014 Stan badań nad miastami wielkopolskimi w latach 1992-2012. Wielkopolskie Sprawozdania Archeologiczne, 14, s. 243-261.

Pruchniewska A.

1987 Mosina w legendzie i zwyczajach. Ziemia Mosińska, 3(1987).

Roszak F.

1987 Korzenie naszego istnienia. Ziemia Mosińska, 9(1987).

Roszak F.

1986 W 41. rocznicę wyzwolenia. Ziemia Mosińska, 1-2(1986).

Sulimierski F., Chlebowski B., Walewski W. (red.)

1885 Stownik geograficzny Królestwa Polskiego i innych krajów stowiańskich (t. VI). Warszawa.

Sobczak J.

2007 Napoleon w Wielkopolsce. Spotkania z Zabytkami, 2, s. 27-29.

Szeszuła J.

2012 Budynek nr 7 na rynku w Mosinie. [Maszynopis w posiadaniu autorów].

Wawrzyniak P.

2003 Kafle piecowe w zbiorach byłej Pracowni Naukowo-Badawczej PKZ Sp. z o.o. w Poznaniu. Wielkopolskie Sprawozdania Archeologiczne, 6, s. 189-217.

\section{A FEW WORDS ABOUT MOSINA \\ (IN THE CONTEXT OF ARCHAEOLOGICAL EXCAVATIONS CONDUCTED \\ IN THE OLD TOWN IN MOSINA IN 2011)}

\section{Su m mary}

The archaeological excavations conducted in the spring of 2011 in yard No. 7 in vicinity of old market at Plac 20 Października (20th October Square) were the first in the history of the town large-scale investigations of residential urban area in Mosina. There were two levels of former developments recognised, dating from the fifteenth and seventeenth/eighteenth-centuries, in a front part of a plot located in a western frontage of a market in Mosina. Underground parts of buildings, which might have had arcades, were located about 1.5-3.5/3.9 $\mathrm{m}$ from the front elevation of the present-day house. Neither further development and land use within the plot nor the depth of the 
foundation of the building dating from the modern period, have been recognised. However, the observation has been made that the area at the back of the plot might have been either cultivated or gardened, probably with vegetables.

It was pottery from the assemblages, steel-gray from the fifteenth-century, and brick-coloured or "pseudo-maiolica" from seventeenth- and eighteenth-century respectively, which appeared to provide dating evidence. No older material has been recorded. The striking absence of materials dating back to the deep Middle Ages speaks in favour of a hypothesis promoted by some researchers, of a possible translocation of Mosina from neighbouring Niwka at the beginning of the second quarter of the fifteenth century, i.e. at the time when Władysław Jagiełło issued a new foundation charter to the town. Mosina might have been been originally located in the area of today's bridge and wastewater treatment plant, where more than 25 years ago a large settlement from the turn of the fourteenth century was discovered, and after two centuries, by royal decision, transferred to its present location. However, further archival and cabinet studies would be required to prove this thesis, including in-depth analysis and publication of the results of excavations of the above mentioned settlement and also interdisciplinary archaeological research of the historical town centre.

Translated by Lucyna Leśniak 